2018-09

\title{
Interaction between Musical and Poetic Form Affects Song Popularity: The Case of the Genevan Psalter
}

\section{Schotanus, Y}

http://hdl.handle.net/10026.1/11820

\subsection{7/pmu0000216}

Psychomusicology: Music, Mind and Brain

American Psychological Association

All content in PEARL is protected by copyright law. Author manuscripts are made available in accordance with publisher policies. Please cite only the published version using the details provided on the item record or document. In the absence of an open licence (e.g. Creative Commons), permissions for further reuse of content should be sought from the publisher or author. 
Interaction Between Musical and Poetic Form Affects Song Popularity: the Case of the Genevan Psalter

Yke Schotanus

Utrecht University, Utrecht, The Netherlands

Hendrik Vincent Koops

Utrecht University, Utrecht, The Netherlands

Judy Edworthy

Plymouth University, Plymouth, UK

Author Note

Yke Schotanus, Institute for Cultural Inquiry (ICON), Utrecht University, Utrecht, the Netherlands.

Hendrik Vincent Koops, Department of Information and Computing Sciences, Utrecht University, Utrecht, the Netherlands

Judy Edworthy, Cognition Institute, Plymouth University, Plymouth PL4 8AA, UK

This research is made possible by NWO and SG het Rhedens, by granting the first author the opportunity to avail himself of a PhD scholarship for teachers. The first author likes to thank his supervisors (Emile Wennekes (Universiteit Utrecht), Frank Hakemulder (Universiteit Utrecht) and Roel Willems (Nijmegen University) for their support and comments. Furthermore, he would like to thank several people who helped him collecting data: Machiel Karels (Psalmboek.nl); Maaike Oosten, Anje de Heer and the Steunpunt Liturgie of the Gereformeerde Kerken vrijgemaakt (GKv); H.N. Werkman; and all the ministers, organ players and church members that collaborated in this research. Special thanks 
he owes to the second and third author and the reviewers of Psychomusicology: Music, Mind, and Brain, who helped him restructure and improve this paper.

No part of this paper is published earlier in any form, except for a presentation at Utrecht University: Schotanus, Y.P. (2016-11-24) Colloquium in the Musicologies, Interaction Between Musical and Poetic Form Affects Song Popularity: The Case of the Genevan Psalter. Utrecht.

Yke Schotanus (The Hague, 1963) is PhD candidate at Utrecht University, working with a NWO PhD scholarship for teachers. Furthermore he is a secondary-school teacher Dutch Language and Literature, a writing coach, and a singer-songwriter.

Hendrik Vincent Koops (Oss, 1984) is a PhD candidate in computer science at the Utrecht University, focusing on computationally modeling harmonic variation and subjectivity.

Judy Reed Edworthy (Newton Abbot, 1957) is Professor of Applied Psychology and Director of the Cognition Institute at Plymouth University, UK. She has published many articles on the psychology and design of audible alarms, and also occasionally on the cognitive psychology of music.

Correspondence concerning this article should be addressed to Yke Schotanus, Veerweg 40, 6991 GP Rheden, The Netherlands. Email: schotschrift.teksten@planet.nl 


\begin{abstract}
Differences in the popularity of individual psalms and melodies from the Genevan Psalter, both in The Netherlands and elsewhere, offer an interesting case study for investigating factors that might influence the popularity of a song. The Genevan psalms form a relatively small set of hymns $(N=150)$ that has long played an important role in Dutch cultural life, and it is clear that some psalms are more popular than others. Previous researchers have shown that contents and musical mode influence popularity. In this paper we present evidence that interaction between melodic and poetical features also affects song popularity, presumably by affecting processing fluency. Pilot studies generated a set of preference rules, operationalized in two multinomial factors repetition and balanced motion. These were tested in three subsequent studies, in regression analyses on scales indicating the popularity of Genevan psalms or melodies in specific 'arenas' (i.e. countries, denominations, and era), both separate regressions and regressions with full models including variables concerning contents, mode, and length. Both repetition and balanced motion turned out to be significant predictors in all regressions. Furthermore, the specific way many Dutch protestants have sung the psalms through the ages plays a part in this interaction.
\end{abstract}

Music and language - Repetition - Musical form - Poetics of song lyrics - Mode 


\section{Introduction}

From Greek antiquity until the present day, perhaps earlier, philosophers, politicians, spiritual leaders, researchers, poets, and musicians have speculated about the interaction between music and language in songs (Winn, 1981; Kirby Smith, 1999), though little empirical data exists on this topic. However, in the last few decades, findings in the field of music cognition and the poetics of song writing have shed new light on this relationship. The popularity of a song seems to be influenced by the way the structure of both music and lyrics influences listeners' expectations, and affects processing fluency and attention (Huron, 2006; Pattison, 2009, among others).

A 'natural experiment' on this topic can be seen through the emergence of the Genevan Psalter, where melodies and text interact in a range of quite complex ways. It is clear that some psalms are more 'popular' than others - or at least, some are used and favored more than others - which leads to a question that hitherto has remained unanswered satisfactorily: which factors would have influenced, and still influence, the usage and the popularity of the psalms?

The Genevan Psalter is a relatively small body of songs (150 psalms plus twelve other biblical hymns) that have long played a very important role in Dutch cultural life. It was created and 'tested' over a period of twenty-six years (1538-1564) in the community of Calvin, first in Strasbourg, and later in Geneva. From 1619 until the beginning of the twentieth century for most Dutch protestants the hymns from the Genevan Psalter were the only songs they were permitted to be sung in church, and even now there are denominations in which this is still the case. Surprisingly, even in this psalm-centered culture a lot of psalms are seldom sung (Smelik, 1997; Luth, 1986, 2004; Polman, 1965; Werkman, 1991/1992; Polder, 2001; 't Hart, 2012), although school children had (and often still have) to learn a stanza by heart weekly. The fact that some psalms are more popular than others leads to the 
question as to whether there are intrinsic, structural features of those psalms which affect their popularity and use. In this paper we explore the possible factors in detail.

First it is important to consider the historical and ecclesiastical influences which might have shaped the way the use of psalms has evolved. At the time of introduction, most churchgoers were unable to read either language or music, the way in which psalms were sung in the Netherlands was slow, and singing was largely unaccompanied (Luth, 1986, pp. 146-162 \& 186-209; Luth, 2004, pp. 429-430). This goes some way to explaining why only a relatively small number of psalms fell into general use but does not explain which psalms would be the psalms that became relatively popular. Conversely, the fact that Dutch protestant services have been a relatively protective environment for the Genevan psalms has probably enabled psalms that would not become popular outside the Dutch services to do so, because there these psalms and their 125 melodies (see Appendix I) had to compete with other hymns.

Also very important is the fact that from 1619 until 1778 the rhyming version of the Genevan Psalms by Datheen was the only rhyming versions allowed in Dutch services. This rhyming version is known to contain an excessive number of metrical misalignments (Meijer; 2004, p. 442; Schenkeveld-van der Dussen, 2004, Beelen, 2004), and therefore might have caused the slow an isometric way of singing (Polder, 1965) that became customary only in the Netherlands (Luth, 1986, 2004). In isometric singing, every note in a musical phrase is treated as a semi-breve. Lengthening notes is a well known way to mask metrical misalignments in songs (Palmer \& Kelly, 1993), and in slow isometric singing the musical tactus becomes less perceivable. Hence, although in the sixteenth century both syncopations and misalignments caused difficulty (Luth, 1986, 2004), in the period following (at least until 1938) the way of singing has mitigated this effect, and subsequently neither Datheen's misalignments, nor the syncopations in a lot of psalms (especially those by Bourgeois (Gutknecht, 2004)), can have affected the preference for some psalms over the others directly, or in a substantial way. 
Two of the aspects of which musicologists Smelik (1997) and Luth $(1986,2004)$ have theorized that they might be important for the popularity and the use of psalms have indeed been shown to feature relatively often in popular psalms. These are the contents and mode (Smelik, 1997; Polder, 2001; Marti, 2004). However, recent literature on the cognition of music and the poetics of song writing suggests other additional, previously not considered factors which might influence the relative popularity of psalms or melodies in the Genevan Psalter. Most of these factors appear to have something to do with processing fluency, which will be the focus of the studies in this paper.

Processing fluency is known to support liking to a certain extent (Huron, 2013; Bornstein \& d'Agostino, 1994). Moreover, when psalms were first used congregations were typically able to read neither words nor music. Psalms would thus have to be learned, and the propensity of the psalm for learning would have some influence on the uptake of individual psalms. Although nowadays most churchgoers read and are used to music notation, learning the melody is still important. Even now ministers choose to prescribe tunes well known by the crowd, in order to support crowd-singing ('t Hart, 2012). This doesn't mean that psalms need simply to be short and avoid arty rhetorician-like rhyme schemes, as Kloppenburg (1991, pp. 243-240) has suggested. Shortness and plainness will of course support processing fluency, and indeed there are psalms with short and plain stanzas which have become very popular (for example psalm 134 (Old hundredth for the Anglo-Saxon world, see Figure 1). However, earlier research has already shown that length as such cannot predict psalm popularity (Smelik, 1997; Marti, 2004). Moreover, during the last few decades, several scholars have shown that there is an inverted-U-shaped relationship between complexity and aesthetic valence (Berlyne, 1971; North \& Hargreaves, 1995; Chmiel \& Schubert, 2017), which would indicate that somewhat more complex psalms might be more popular than the simplest ones. 
Therefore, most of the factors we will discuss here are thought to explain why a longer psalm can be popular regardless of its length.

What follows is a description of the theories behind the predictions concerning processing fluency, and the way these hypotheses have been developed, operationalized, and tested.

\section{Pilot}

\section{Introduction}

Before describing the main experiments of this paper, we first discuss a pilot study we performed. In this study, we made a first analysis of the dataset, which shaped the way we performed the main experiments (Study I-III). When we started the pilots, our assumptions were these:

1. Verbatim repetitions of musical phrases support processing fluency (on the basis that something familiar is easier to process than something new) and subsequently support popularity, especially when repetitions occur at the beginning of the stanza (Huron, 2013; Ollen \& Huron, 2004). Repetitions that occur later could possibly have a detrimental effect on popularity (Schotanus, 2007; Schotanus, 2015).

The focus is on verbatim repetitions as we think these are relatively easy to recognize compared to, for example, transposed or varied repetitions. Verbatim repetition should require the absolute minimum cognitive load. Repetitions of rhythmical patterns, such as the one in psalm 134 (Figure 1) with its alternation between fast notes in the first part of each line and three long ones at the end, might also be easy to recognize, but not necessarily in isometric singing.

2. Segmentation supports memory (Neath \& Brown, 2006) and thus popularity, and although the psalms are presented as AAA-shaped strophic songs, many of them consist of two-part stanzas, similar to most sixteenth-century French strophic 
songs (Naudin, 1968, pp. 110-111). Segmentation can be measured by a tonic in the melody halfway through the stanza, a shift of rhyme scheme, line length or meter, or by a specific pattern of melodic repetition.

In addition to supporting memory, segmentation might also support attention to the lyrics, by creating a dishabituating break that prevents the listener from boredom or trance, which can be caused by highly repetitive music, such as a strophic song (Huron, 2013).

3. $\mathrm{AAB}$ and $\mathrm{AA}$ 'B shaped melodies are even more popular than other melodies with repetitions, because they occur at the beginning of the stanza and they create segmentation.

4. Textual properties that support predictions about what is to come (for example, how many lines will follow, or at which point in time a sentence will end) support processing fluency and popularity. Especially, alternating rhyme schemes (i.e. abab, or other rhyme schemes with a simple recurring pattern other than paired, in this corpus: aabaab, aabccb and abbacc) and alternating line lengths (following similar patterns, for example: long-short-long-short, or: short-short-long-shortshort-long) support processing fluency and popularity.

In line with theories on both musical meter (Aroui, 2006) and poetic meter (Temperley, 2001, p. 39) Pattison (2009) assumes that song (or at least Western song) tends to be organized in a binary fashion, with more or less equally weighted parallel parts. Listeners expect a song to be balanced that way. Hence, as long as balance is delayed, listeners will expect the song to move on. Such an expectationbased sense of moving forward he calls 'motion'. Similarly, musicologists speak of harmonic or melodic 'motion' when they discuss the way harmonic or melodic 
tension make the listener expect a song to move on until it ends on the tonic (Burns, 2002, among others).

Pattison argues that certain rhyme schemes, especially alternating ones, create motion, while others, such as aabb, create stops. If the rhyme scheme is aabb the expectations never move beyond the next line, while other rhyme schemes make one look further ahead. For example, compare the first stanza of Psalm 134, quoted above (see Figure 1), with the first stanza of 140:

"LORD, rescue me from foes, I pray Thee;

From all their fury, save my life.

Their hearts plan evil to betray me;

They daily stir up war and strife.” (Kamp, 1972)

In 134, after the second line, the listener does not know what to expect - the psalm might possibly be finished. In 140 the listener will expect two four-feet lines, with at least one rhyme at the end of the second. Similarly, in a place where a long line is expected, a short line might create motion. If, in 140, the last line was: 'They daily stir up strife', the stanza would feel unfinished. In the same way, alternating line lengths and uncommon rhyme schemes (all examples of the rhetorician-like artiness Kloppenburg thought to be detrimental to popularity) might serve as deliberately chosen techniques to surprise, draw attention, and keep a song moving on (Pattison, 2009; Schotanus, 2007).

5. Lines consisting of more than four metrical feet (i.e. returning patterns of weak and stressed syllables) have an adverse effect on popularity.

A four-feet line (such as: You fáith- / full sér- / vants óf / the Lórd (psalm 134)) or a musical phrase consisting of 8 notes is thought to be a perceptual optimum (Aroui, 2009; Temperley, 2001, p. 69) 
6. Shortening line lengths towards the end of the song support processing fluency and popularity.

7. The longer the stanzas of a psalm, the more important are these properties in supporting processing fluency, because they work against length.

8. In denominations singing isometrically the importance of repetition, rhyme scheme, and line length is more important than in denominations singing rhythmically.

Several other properties which might help processing fluency are not perceivable in slow isometric singing. In countries were the Genevan melodies had to compete for popularity with other hymns, the propensity of melodies to be learnable will be even more important.

\section{Method}

Twenty-seven mostly dichotomous variables were created as described in Appendix IIa). Furthermore, several dependent variables were created indicating psalm popularity in specific arenas (i.e. denomination, country, or era, see Appendix IIb). Because most of the variables were thought to affect longer psalms more clearly than shorter ones, linear regressions were conducted both on the complete dependent variables and on subsets of them based on stanza length.

\section{Results and discussion}

The results of this pilot study were too fragmentized to warrant full reporting. Furthermore, the use of linear regressions was limiting because the dependent variables were ordinal. Moreover, we created the dependent variables by combining other ordinal variables in a doubtful way: we simply added up the values for each psalm in the different variables.. Nevertheless, the results seemed to be consistent with several of our assumptions. However, 
we lacked data on psalm popularity in denominations singing rhythmically. Furthermore, there were results that seemed counter-intuitive. Segmentation, for example, often seemed to have an adverse effect on popularity; alternating rhyme scheme sometimes seemed to predict unpopularity in shorter psalms; lines longer than four feet did not predict unpopularity, although they did not exist in longer psalms; in America six-line psalms were relatively unpopular while four and twelve-line psalms are extremely popular; and several minor predictions did not show any significant effects . These observations led to a reassessment of the factors and our hypotheses about them, as well as leading to refinements in the way that the independent and dependent variables were formulated and operationalized.

We did not drop our major assumptions concerning segmentation, motion, and balance and their operationalization, but realized some of these assumptions conflicted and interacted with each other. Hence we needed to search for theoretically substantiated predictions about the nature and the effect of this interaction. In the first instance, we hypothesized that segmentation might support popularity only if it is also supported by motion. In line with this, Summach (2012) shows that song sections preceding a chorus are less likely to end with the tonic than with another chord. Secondly, we hypothesized that as motion exists by virtue of delayed balance, balance in itself might be as important as motion. Therefore, we would expect a song to be double balanced at the end. Consequently, we adapted Arleo's (2006, p. 44) hypothesis that a basic 'rule' for a children's rhyme (created by children) is that the amount of lines in a strophe is a power of two (i.e. $2,4,8,16$ ). We would say that ideally a stanza in a strophic song is double balanced, for example by number of lines. This would exclude two- and six-line psalms but include twelve-line psalms, and is in line with Aroui (2006, p. 29) who, comparing six and twelve-line stanzas, states that 'The higher the metrical structure's level, the more its end tends to correspond to a major syntactic boundary'. Aroui's statement indicates that the higher the metrical structure's level, the more the end is associated 
with closure (i.e. balance). Therefore, twelve-line stanzas can be considered to be double balanced as well. However, the principle of double balance does not involve only the number of lines, it also allows for other factors (rhyme scheme, line length, a tonic halfway through the psalm) to affect balance as well. For example, a single balanced six-line stanza in which the $3: 3$ segmentation is accentuated by a tonic at the end of the third line, becomes doublebalanced.

After careful examination of the results we restructured our experiment. We elaborated our principles and operationalized them in fewer independent variables. Furthermore, the structuring of the dependent variables required improvement; additional data concerning denominations singing rhythmically had to be collected; and the regressions needed to be ordinal in nature.

Preference rules - The process of reconsidering our theories and expectations, combined with the need for predictor variables that combine predictions for shorter psalms with those for larger psalms, led to the creation of two new predictor variables, based on a newly-created set of preference rules concerning segmentation, balance, and motion. These are as follows:

Preference rule 1: Preference for stanzas which are double balanced at the end (i.e. preference for stanzas with four, eight or twelve lines, or stanzas in which a disbalance in number of lines is compensated for by balance on another level).

There can be balance on several levels, including melody, harmony, line length, phrasestructure, amount of lines, linguistic syntax, and rhyme scheme. (In our research we do not consider the harmony of the accompaniment. The harmonies are not explicitly prescribed and organ players often vary freely in their choices, therefore the variance of harmony is too large and variable to be taken into account.) Lack of balance corresponds to motion (a sense that the song is moving on) as long as it can be perceived as delayed balance. 
Preference rule 2: Preference for stanzas in which there is motion (or delayed balance) during the song, i.e. stanzas in which there is some kind of disbalance during the song, which reinforces the prospect of balance at the end, and helps the listener to predict what will come.

Strong indicators of balance are, for example: a tonic at the end of a musical phrase (which is known to affect language processing by suggesting linguistic closure (Curtis et al., 2005)); equal line lengths (depending on language and kind of music, either an equal number of syllables, metrical feet, or stressed syllables in combination with the same rhyme type (masculine, feminine)); equal or parallel musical phrases (basically equal in measure structure and total duration, but the more equal (regarding number of measures, note durations, rhythmical patterns, pitch contour etcetera) the stronger the sense of balance); paired rhyme, or the ending of a sentence (in this corpus marked by a period).

Some strong indicators of motion (or delayed balance) are: a dominant at the end of a musical phrase, an enjambment, a comma, alternating rhyme schemes (see above), or shortening line lengths.

Preference rule 3: Preference for stanzas in which a strong indication of balance 'halfway' through the stanza is combined with disbalance (Motion) on another level, thus creating helpful segmentation.

A combination of Pr1 (Preference rule1) and Pr3 will prescribe that helpful segmentation occurs exactly halfway through the stanza by preference. However, there are other options. For example, in six-line psalms a 4:2 division might be even more preferable than a 3:3 division, as 3:3 is just single balanced in terms of number of lines, while 4:2 is double balanced. 
Preference rule 4: Preference for melodies in which the first melodic phrase or line is repeated verbatim somewhere in the stanza, especially if such a repetition results in an AAB or AA'B shaped stanza.

Preference rule 5: Preference for melodies in which the first melodic line of a B section is repeated verbatim somewhere in this section if, and only if, $\operatorname{Pr} 3$ or $\operatorname{Pr} 4$ is met.

Preference rule 6: Preference for verbatim repetitions of melodic lines other than the opening phrases of section A or B in which Pr2 is met.

$\operatorname{Pr} 5$ and Pr6 are thought to be weaker than Pr4, because the kind of repetitions described here are relatively complex and might require some exposure to be preferred.

Preference rule 7: Preference for shortness (i.e. shorter lines and shorter stanzas).

Operationalization - One dichotomous variable and two multinomial variables were created by applying these preference rules to the psalms. The dichotomous variable foureighttwelve distinguishes between psalms with four, eight or twelve lines per stanza, and other psalms. The multinomial variables, balancedmotion and repetition, were more complex.

Balancedmotion - This variable consists of seven categories. These are six categories of psalms which are predicted to be relatively popular for a specific reason, and one category of psalms which are predicted to be unpopular. The predictions are always related to the number of lines per stanza. If the number of lines is high $(>8)$ or short but double balanced (4 with a paired rhyme scheme), features that are hypothesized to create motion and segmentation will be used as predictors of popularity, and if the number of lines is low and lack balance $(5,6$ or 7$)$, features that are hypothesized to create balance will be used as such. We did not put all the psalms hypothesized to be popular in one category, in order to be able to investigate the effect of each set of predictions separately. As there are just a few nine and 
ten-line psalms, and there are many options to compensate the lack of balance in these longer psalms, there will be no predictions concerning balance in these psalms, thus the categories would become too small. In this study, they will be treated as longer psalms, which need motion. Hence, we have created the following categories:

- Long alternating: longer psalms (i.e. psalms consisting of eight lines or more) with an alternating rhyme scheme, creating motion (see above);

- Long+: longer psalms in which processing fluency is warranted by a combination of features providing both segmentation and motion; there must be a mixed rhyme scheme, and Pr3 should be met (i.e., in this corpus: an AB segmentation with no tonic at the end of the A-part, shorter lines in the B part, or (in Psalm 150) an asymmetric 5:3 segmentation strengthened by an unfinished rhyme scheme at the end of the Apart);

- Tonic 3: Six and seven-line psalms in which the lack of balance caused by the number of lines is compensated for by a tonic at the end of the third line (creating a 3:3 segmentation, and preventing the fourth line to be perceived as a final line in several rhyme schemes);

- 6+: Six and seven-line psalms without a tonic at the end of the third line, in which the lack of balance caused by the number of lines is compensated for in a different way than mentioned above. Lack of balance is compensated for using the irregular rhyme scheme abaccb in which a strong sense of closure is created by a delayed b; by a $4: 2$ segmentation created by rhyme scheme (in this corpus: ababcc or aababa); or by a $4: 2$ segmentation created by either shortening or lengthening the last two lines, for example by using masculine rhyme instead of feminine rhyme or vise versa. In this case even longer closing lines are acceptable, as a 4:2 segmentation is a way of shortening already $(6+)$; 
- 5+: Five-line psalms ending with a short line (i.e. a line consisting of fewer metrical feet than the other lines) limiting the delay caused by the extra line (the shorter the line, the larger the effect);

- 4+: Four-line psalms in which both balance and motion are optimized by the combination of either paired rhyme with a tonic at the end of the second line, or alternating rhyme with no tonic at the end of the second line, except when only the fourth line is relatively short;

$4+_{\text {rhythm: }}$ An alternative version of this category consists of four-line psalms in which both balance and motion are optimized by the occurrence of a rhythmic pattern dividing each line in two by a caesura, or by maximum shortness (i.e. four-feet lines with male rhyme).

- Other: Psalms in which there might be a problem with either $\operatorname{Pr} 1, \operatorname{Pr} 2$ or $\operatorname{Pr} 3$.

Note that we did not take into account all possible aspects of music and lyrics that might affect balance, motion, and segmentation as the categories would have become too small to be meaningful. Furthermore, for most categories, except for ${ }^{4+}{ }_{\text {rhythm, }}$, we have chosen features which are perceivable in both rhythmic and isometric singing. Nevertheless, we think that some categories will be more popular in congregations singing isometrically, while all categories except 'Other' will predict popularity in congregations singing rhythmically. We think that isometric singing might require features that support motion, while rhythmic singing might induce motion already and give space for features that simply accentuate balance and segmentation to be appreciated. Therefore we expect $6+$ and $4+_{\text {rhythm }}$ to be more popular in rhythmic singing, and Long alternating to be more popular in isometric singing. The properties of Psalms in Long+, Tonic 3 and 4+ all support balance, segmentation, and motion at the same time, and might be popular anywhere. We made the exception of using rhythmical aspects to create $4+_{\text {rhythm }}$, because there are more four-line psalms relatively 
popular in rhythmic singing. Therefore it would be interesting to see whether rhythmical features that are assumed to affect balance and motion, might be able to explain which fourline psalms have become popular among rhythmically singing congregations.

Repetition - Repetition consists of 6 categories generated to test whether there is a difference of predictive power of different melodic repetitions. Most of the repetitions are verbatim repetitions of complete lines, or pairs of lines. In a few psalms a salient sequence of notes in the first line, either the opening or the closing phrase, is repeated verbatim. If it is the closing phrase, the repetition is categorized as a late repetition (see below). A sequence of the same notes is not considered to be repeated verbatim if the accent structure is different, as is the case in Psalm 149 (see Appendix III).

The categories are:

- AAB: Psalms with AAB-shaped stanzas;

- AA'B: Psalms with AA'B-shaped stanzas (in an AA'B-shaped stanza, the A-part shows some variation towards the end);

- $\quad 1^{\text {st }}$ line: Other psalms in which the first musical phrase is repeated verbatim;

- $\quad$ Late +: Psalms which meet Pr5 or Pr6;

Meeting Pr5 would require that psalms in which the first musical phrase of the Bpart is repeated; psalms in which the A part does not end on the tonic, or ends with a shortened fourth line; or psalms in which the line lengths in the B part are shortened.

Meeting Pr6 would require that psalms in which the second part of what can be seen as a musical $\mathrm{A}$ is repeated (suggesting an AA'B form); psalms with six-line stanzas in which the melody or the fourth line is a repetition of the melody of the third one, but which does not end on the tonic (preventing a strong sense of closure caused by a paired rhyme ending on the tonic of a fourth line); an eight-line psalm 
in which the melody of the fifth line is a repetition of the melody of the fourth, within an aabccbdd rhyme scheme. Due to rhythmical issues in one case (Psalm 23) the repetition may be barely perceivable in isometric singing, and in two cases Pr5 might not be met in isometric singing (Psalms 29 and 149 (see Appendix III)).

- No repetition: Psalms without clear verbatim repetitions;

- Late-: Psalms with repetitions that do not meet Pr4, nor Pr5, nor Pr6, including a hard-to-categorize psalm in which the first line of the B part is a repetition of the second line of the A part and in which the A part is a five-line stanza ending on the tonic.

To test the predictive power of these variables we have performed three studies by conducting regression analyses on datasets indicating the popularity of psalms in specific arenas. The psalms were rated in three different domains:

- Psalms used in Dutch religious denominations singing isometrically, (both between 1850 and 1938 and in the early 2000s) (Iso);

- Psalms use in two different contemporary Dutch denominations singing rhythmically $(P K N$ and $G K v)$;

- Use of Genevan melodies for either contrafacts (different lyrics to melodies used in other psalms) or Genevan psalms in hymnals in North America (America), in noncalvinist Germany before 1900 (Germany) and in the Netherlands before 1900 (CfIso). Several of these datasets existed prior to the studies. However, for PKN, GKv, America, and Germany, the data were collected by the first author. For PKN, data were collected through ministers and organ players; for GKv an online survey was published on the GKv website; for America the website Hymnary.org was searched for mentions of Genevan melodies used for hymns in North-American hymnals, and for Germany two articles 
were searched for mentions of Genevan melodies occurring in hymnals used in non-

Calvinistic Germany (Scheitler, 2004; Leaver, 2004).

In Study I the newly created variables were tested separately in regressions on several PKN and Iso-related dependent variables. In Study II they were tested in full models alongside several other predictors of psalm popularity, and on several PKN, Iso, and GKvrelated dependent variables. Study III tested the variables in relation to the contrafact scales, as analyzing those scales presents several new and different methodological problems. Table 1 provides a general view of the Independent variables and their levels in the different studies.

\section{Study I}

\section{Introduction}

In this study, we perform a series of regressions to determine the effect of repetition and balancedmotion on five indicators of psalm popularity in both isometric and rhythmic singing context.

\section{Method}

Independent Variables - In Study I both repetition and balancedmotion were used in two versions.

Repetition - In a few cases aspects of the melody that are thought to support a late repetition in rhythmic singing are not perceivable in isometric singing (see Appendix III for an example). Therefore, we created a version of repetition, Repetition ${ }_{\text {iso, }}$, in which these psalms are in the category Late - while they were in Late + in the original variable Repetition $_{\text {rhythm }}$

Balancedmotion - Since there are two versions of $4+$ there will also be two versions of balancedmotion. Balancedmotion ${ }_{\text {iso }}$ with $4+$, and balancedmotion rhythm $_{\text {with }} 4+_{\text {rhythm. }}$ 
Dependent variables - We created two variables with a comparable datastructure, one Iso-related (Iso) and one rhythm-related (PKN), and one variable with a totally different datastructure (Psalmboek).

$P K N$ is based on seven counts or assessments of psalms sung in services, received from five ministers and two organ players from the unorthodox division of the biggest Dutch protestant denomination, the Protestantse Kerken in Nederland (PKN). The ratings were collected by the first author by e-mail. One minister categorized all psalms into four categories, whereas five ministers and organ players simply provided lists of the psalms sung most often, categorized either in one or in two categories. One minister provided a complete record of psalms he had prescribed in the preceding five years (one per service, $\mathrm{N}=114$ ). The first author counted the psalms in this record and categorized them. Here, all psalms sung were categorized as either popular or somewhat popular, as even the occurrence of psalms sung once in 114 services is above chance. Appendix V provides an overview of the measurements in the PKN dataset. Cronbach's alpha (Cronbach, 1951) for these measurements is .824 , indicating a high reliability.

Iso is based on: three counts of psalms sung in individual churches in the $19^{\text {th }}$ century; one count of psalms prescribed in devotional diaries and volumes of sermons (Gunning, 1910, quoted by Smelik (1997); one count of psalms quoted in Dutch hymnals between 1866 and 1938 (Smelik, 1997); and two counts of psalms sung in individual churches at the beginning of the $21^{\text {st }}$ century (Polder, 2001; 't Hart, 2012), see Appendix IVa. Cronbach's alpha for these counts is .879 .

Psalmboek: The number of times a psalm was clicked on at the website Psalmboek.nl (Karels, 2013) was used as an additional test variable. This website presents the psalms sung isorhythmically, and hence, might reflect the popularity of psalms in the isorhythmicallysinging Dutch community. However, clicking a psalm does not have to mean listening the entire 
psalm, let alone singing it, therefore we did not work up a categorized version of this variable in Iso.

Scale construction - As the data obtained for PKN and Iso consisted of both counts and ratings, which were sometimes only approximate and at other times very specific, normalization was necessary. All indicators of popularity were either reduced or extended to ordinal scales with roughly the same categories (see Table 2 for an overview). We chose fourcategory scales with the following categories: relatively popular (value 3); somewhat popular (value 2); not so popular (value 1); really unpopular (value 0). Missing values were set to zero in order to be able to compute means in SPSS. So, if a top-ten only had been provided initially, 140 psalms (150 total - 10 mentioned) were categorized as unpopular although it is likely that some of them would be categorized as somewhat popular if further information had been available. Setting missing values to 0 skews the distribution towards unpopular songs, which is in line with the fact that in most cases the psalms for which we do nothave values are less popular.

The consequence of this approach is that the criteria for a psalm to be categorized as 'relatively popular' and 'somewhat' popular were fairly dissimilar across scales. Moreover, we do not have direct information as to which criteria the ministers and organ players were using while categorizing, and often there is a lack of information as to how often the psalms not mentioned are sung or used. Even the exact counts could not be categorized according to exactly the same rationale. Furthermore, the Genevan Psalms are sung less often in PKN than in denominations singing isometrically. Consequently, a psalm sung once in a year in PKN church might be considered popular, while a psalm sung once a year in a community singing isometrically must be considered unpopular. However, the key element of our scaling was to preserve relative popularity of some psalms over the others within denominations. 
After categorizing the counts and ratings in a similar way, we established the means per psalm for both Iso and PKN. Subsequently, we recategorized the variables created this way, because using the means as a linear variable implied a level of accuracy which did not exist. However, we could not use exactly the same criteria for categorization. This becomes clear from a visual inspection of Figure 2. What is striking is that in PKN more psalms have a relatively high mean, while in Iso a few psalms have a very high mean. This might indicate that in PKN there is more variation in psalms that have become relatively popular, which is in line with the higher Cronbach's $\alpha$ value for Iso (mentioned above).

We have tried to reflect the differences in the distribution of the means in our categorization of PKN and Iso, while keeping the category-sizes fairly comparable (see Table 2.). (Criteria Iso: values $\geq 1.71$ (outliers), popular; values $<1.71$ but $>0.75$, somewhat popular; $\leq 0.75$ but $>0$, not so popular; 0, unpopular; Criteria $\mathrm{PKN}: \geq 2$, popular; $<2$ but $>1$, popular; ; $\leq 0.75$ but $>0$, not so popular; 0 , unpopular.)

Statistical analysis - Because ISO and PKN were ordinal dependent variables, the regressions on these scales were preceded by a test for potential problems with multicollinearity and a Test of Parallel Lines, in order to investigate whether the assumption of proportional odds was met. The test of Parallel Lines is a full likelihood ratio test, comparing the fitted model to a model with varying location parameters. Separate binomial logistic regressions on cumulative categories of the dependent variable were used to further investigate the assumption of proportional odds, whether or not the test of Parallel Lines was passed. The ultimate cumulative odds ordinal logistic regressions with proportional odds were performed using the Generalized Linear Models (GZLM or GENLIN). In addition, the output of the PLUM procedure was used for supplementary information concerning the Deviance goodness-of-fit test, the Pearson goodness-of-fit test, and pseudo $R^{2}$ factors. PLUM is a procedure to model the dependence of an ordinal categorical response variable on a set of 
categorical and scale independent variables. To better identify the predictors of Psalmboek we conducted Poisson-log-linear regressions using GZLM. These are logistic regressions suited for exact counts, which usually have a distribution with a relatively low median and relatively high maximum scores, which should not be treated as outliers.

In addition, Classification and regression trees (CART) regressions (Breiman, Friedman, Stone \& Ohlsen, 1984) regressions were conducted, using the same models. CART regressions try to branch off groups of cases from the whole dataset with a significantly higher mean than the rest, resulting in a so-called decision tree. Each split is based on just one variable, however, CART keeps track of the variables that might have been used for alternative but less powerful splits, resulting in a value for relative variable importance (Rvi). CART regressions were used for two reasons. In the first place, CART analyses always provide an $R^{2}$ learn before cross validation, and an $R^{2}$ test afterwards. In SPSS, cross validation is more difficult to achieve. Moreover, the Poisson-log-linear regressions do not provide any $R^{2}$ values. Of course, Generalized linear regressions are totally different from CART trees, however the comparison with CART will at least provide an indication of effect sizes.

\section{Results}

Descriptive statistics - In Table 3 the distribution of categories of repetition and balanced motion over PKN and Iso is presented. It shows that in Iso, $1^{\text {st }}$ Line seems to be more popular, while in PKN AA'B and Late+, Long+ and 4+ seem to be more popular. Furthermore, PKN and Iso look quite similar. However, the table does not distinguish between popular and very popular.

Regressions with repetition - Table 4 shows the results of regressions with repetition on Iso and PKN. Repetition turns out to be a significant predictor of both Iso and PKN, 
though $R^{2}$ is larger in regressions with Iso. Moreover, all categories that were hypothesized to predict popularity do indeed do so, while Late-, as expected, does not. Furthermore, AAB is the strongest predictor within repetition; $1^{\text {st }}$ Line is substantially stronger in regressions predicting Iso than those predicting PKN; and repetition ${ }_{\text {iso }}$ is a stronger predictor for Iso than repetitionr $r_{\text {hythm. }}$

The additional poisson-log-linear regressions on Psalmboek shows that, as expected,

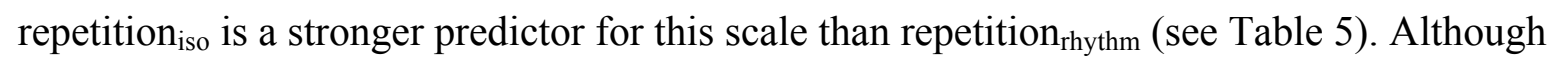
$R^{2}$ for this regression is much lower than $R^{2}$ for the ordinal regressions on Iso, all categories of repetition turn out to be highly significant $(p<.001)$. Admittedly, the odds for these categories are lower in these regressions than in the one conducted on Iso, but the confidence intervals are much smaller.

The poisson log linear regression on PKN count does not reveal reliable results either in SPSS nor in CART. Nevertheless, it is evident that the eleven psalms in Late- are absolutely not popular. The lack of significance might partly be due to the fact that there are just 27 psalms with a count higher than zero according to this count.

Balanced Motion - Neither one of the versions of balancedmotion could be used for an ordinal regression on PKN or Iso. Separate binominal logistic regressions on cumulative categories of the dependent variable revealed several categories with quasi-complete separations which could only be resolved by combining unrelated categories, thereby blurring and weakening the results. Because of these numerical problems, the test of Parallel Lines could not be computed. The five-line psalms that were thought to be popular turned out to be unpopular, while several other categories seem to be popular, or at least not unpopular. However, CART did not encounter these numerical problems. A CART tree predicting PKN with balancedmotion ${ }_{\text {rhythm }}$ predicted $11 \%$ of the variance (Relative Error: .89; $R^{2}$ Learn: .14), indicating that Long+, Long alternating, $6+$ and $4+$ were more popular than the other 
categories, while a tree with balancedmotion ${ }_{\text {iso }}$ was less predictive $\left(R^{2}\right.$ Learn: .13; $R^{2}$ Test: .09). A CART tree predicting Iso with balancedmotion ${ }_{\text {iso }}$ predicted 9\% (R.E.: .91; $R^{2}$ Learn: .13) of the variance, indicating that Long+ and Long alternating are more popular than the other categories. In this case the tree with balancedmotion rhythm $_{\text {was }}$ just as predictive, but slightly less reliable ( $R^{2}$ Learn: .16; $R^{2}$ Test: .09; R.E.: .92).

As Table 6 shows, the poisson-log-linear regressions on the exact counts revealed that all categories of psalms that were thought to predict popularity turned out to do so significantly, except for $5+$. An unexpected result is that balancedmotion rhythm $_{\text {is not only a }}$ stronger predictor compared to balancedmotion ${ }_{\mathrm{iso}}$ for $\mathrm{PKN}$, it is also a stronger predictor for Psalmboek.

\section{Discussion}

The regressions in this study show that all of the categories of repetition that were hypothesized to predict psalm popularity, and most of those of balancedmotion, do indeed predict psalm popularity, and repetition does so more clearly in an environment where singing is isometric. Indirectly, this is support for the preference rules underlying these variables. Not all of the regressions were entirely reliable, but in most cases this was due to quasi complete separations, showing that our predictions were correct. Furthermore, in line with our predictions concerning the effect of either isometric or rhythmical singing, repetition iso $_{\text {is a }}$ better predictor for popularity in an isometrically singing environment than is repetition rhythm. $_{\text {. }}$

However, not all results were as expected concerning balancedmotion. The category $5+$ turned out to predict unpopularity rather than popularity, and hence contributes to the predictive power of balancedmotion in the opposite direction to that which was expected.

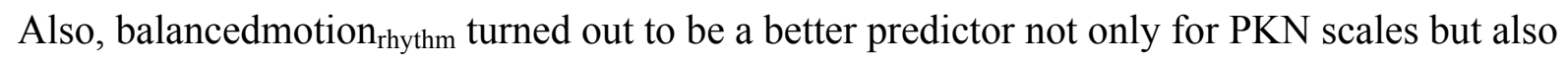
for iso scales. Considering Table 3, this effect is possibly due to the popularity of one psalm, 
which turns out to be Psalm 116 which is also an AAB psalm. Therefore, in a regression with

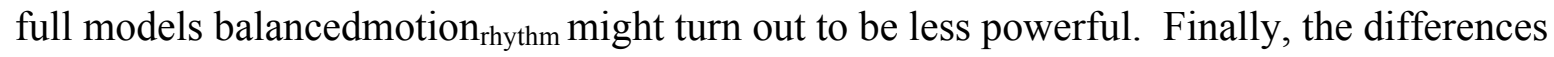
between Iso and PKN concerning the categories are difficult to discuss because the ordinal logistic regressions on Iso and PKN could not be performed.

The ordinal dependent variables PKN and Iso clearly cause difficulty in regressions. The outcomes lack precision compared to those of the poisson log-linear regression on Psalmboek, and correct predictions cause quasi complete separations or other problems with proportional odds. It might therefore be helpful to conduct repeated measures regressions on versions of Iso and PKN in which the underlying scales are incorporated integrally as if they were ratings by different 'subjects' (i.e. a community, a minister, a denomination, etc.).

Further limitations are caused by the fact that we have tested repetition and balancedmotion in separate regressions, although there are other factors which are known to predict psalm popularity and some of these factors might share variance. Therefore, in Study II, we will test whether repetition and balanced motion retain their predictive power in repeated measures ordinal regressions with full models.

\section{Study II}

\section{Introduction}

The main aim of this study was to further test the hypotheses concerning the predictive power of repetition and balancedmotion outlined in the Pilot section in full models, together with other factors that are known or thought to affect popularity. In this study we will use five new independent variables. Furthermore, in this study we are using larger datasets.

Mode - All psalm melodies are written in one of five diatonic modes: Ionian, Aeolian, Mixolydian, Phrygian or Dorian. Psalms in the Ionian mode are known to be relatively popular (Marti, 2004; Polder, 2001; Smelik, 1997). According to Kats (1899) and Smelik 
(1997) this might have something to do with the fact that the diatonic modes had fallen into disuse during the second half of the sixteenth century. Psalms written in the 'old' modes such as Phrygian and Dorian would subsequently have decreased in popularity compared with those written in the Ionian (major) mode and the Aeolian (minor) mode, which became the leading tonalities. However, according to Smelik (1997) the major-like Mixolydian mode might have sounded familiar enough to remain relatively popular. Therefore, Aeolian and Mixolydian are expected to predict popularity, compared with Dorian and Phrygian, though to a lesser extent than Ionian.

Contents - We created two content-related variables. For contents we used the categorization created by Polder (2001). He adjusted all psalms to one of three categories: Psalms that profess God's kingship and omnipotence (Psalms of praise); psalms that contain maledictions or retributions, or lamentations that are too personal to be understood outside the historical context (Negative psalms); and psalms about the relationship between God and his people, and God's promises, including Messianic psalms (i.e. psalms about the Caring God). According to Polder's dataset, Caring-God psalms were often sung, negative psalms seldom, and Psalms of Praise as often as they would if they had been chosen by chance. Smelik (1997) also suggested that negative psalms are unpopular, however, he hypothesized Psalms of praise to be popular. Possibly the popularity of Psalms of praise has changed through the ages.

Doubt - An additional content-related binominal predictor will be psalms of Doubt, based on a list of 'why-asking' psalms Werkman (1992) quotes from Reverend Troost (see Appendix VI). Although the dataset (see Appendix VI) was rather small, the pilot seemed to show that, as Werkman predicted, these psalms are relatively unpopular in a specific Dutch denomination, namely the Gerformeerde Kerken vrijgemaakt (GKv). Therefore, we should include this variable in our regressions. 
Four-eight-twelve - As mentioned before, this is a binomial variable, distinguishing between psalms with or without a double balanced number of lines per stanza. As it emphasizes only balance but not motion, it might be more important as a predictor of rhythmrelated than of iso-related scales.

Stanza length - A covariate, measuring stanza length by counting the number of metrical feet (or stressed syllables) per stanza. We think this is more appropriate than counting lines per stanza. For example, an eight-line stanza with five feet per line is longer (40 feet) than a twelve-line stanza with three feet per line (36 feet).

\section{Method}

Repeated measures ordinal regressions and Poisson log linear regressions were conducted in order to test the predictive power of repetition and balancedmotion within full models.

Independent variables - In each regression we use four multinomial factors (repetition, balancedmotion, mode, and contents), two binominal ones (doubt and foureighttwelve) and one covariate (stanzalength). For an overview of the levels see Figure 1 (Method section, Study I). Repetition and balanced motion will be used in two versions.

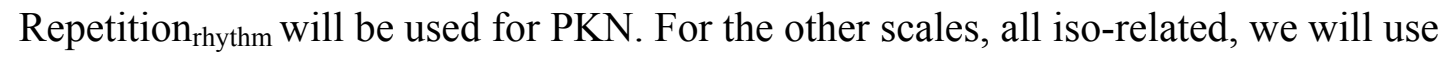

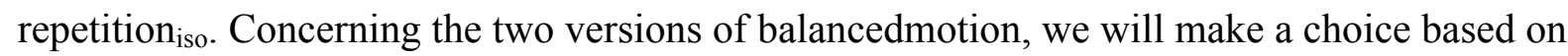
the $R^{2}$ values for the full model in CART.

Dependent variables - We created three main dependent variables:

$P K N$ - a variable which was created using all the scales underlying the PKN version in Study I (see Table 2), except that missing values are left missing rather than being set to zero. Iso - a variable which was created in a way similar to how PKN was created, this time using the scales underlying the Iso version in Study I (see Table 2). 
$G K v$ - is a variable based on an online survey the first author conducted among ministers, organ players, and members of the GKv $\left(N_{\text {valid }}=78\right)$. It was advertised via the GKv-website and website and the newsletter of the GKv Steunpunt voor Liturgie (liturgical support commission). Participants rated on a four-point scale either how often they had prescribed, played or sang the different psalms during the last few decades, if possible since the introduction of the new GKv rhyming version in 1987, or to what extent they knew or liked them. A series of Kruskal Wallis (Kruskal \& Wallis, 1952) tests (one for each psalm) revealed only a few significant differences between groups or type of rating, therefore all of the ratings were combined into one repeated measures variable.

Additional $D V$ - In order to see how the models perform in regressions on a more exact, uncategorized scale, we also tried our models on Psalmboek (see Appendix IVa).

Tests - Repeated measures ordinal logistic regressions, using the Generalized Estimation Equations (GEE) in SPSS, and poisson log-linear regressions, were combined with regressions using CART. GEE's are known to be able to handle both related data and missing values, and the GEE-output is comparable to the GZLM-output in Study I. Just as in Study I, CART regressions were added in order to receive an indication of the predictive power of the model. Moreover, we compare the table of Relative variable importance with the rank order in Wald statistics for the different variables to investigate their relationship. Nevertheless, we have to keep in mind that a relatively large Wald statistic is not necessarily the result of a large effect size, since a small standard error can cause a large Wald statistic as well.

\section{Results}

The repeated measures ordinal logistic regressions on $I s o, P K N$ and $G K v$ show that both repetition and balancedmotion are significant predictors of psalm popularity even in full models with five other factors and covariates, two of which (mode and contents) turn out to be 
important predictors in all regressions too (see Table 7). Nevertheless, both CART and SPSS indicate that in Iso, repetition and balancedmotion are stronger predictors than mode and contents. This effect is magnified by the fact that the model predicting Iso as a whole is much stronger than the models predicting PKN and GKv.

Most of the categories of repetition, balancedmotion, mode, and contents, turn out to be significant predictors of all DVs. Remarkably, for repetition, $1^{\text {st }}$ Line is more important as a predictor of Iso than of PKN or GKv, while Late+ is relatively popular in all denominations and Late- is even less popular than No repetition. In balanced motion 5+ is not significant in any regression, furthermore there is a clear difference between the role of Long+ and Long alternating in Iso on the one hand, and PKN and GKv on the other. For congregations singing rhythmically Long+ is a stronger predictor, while in congregations singing isometrically Long alternating is more important. Another difference between the rhythm-scales and Iso is visible in contents: in the former, Psalms of praise are just as popular as psalms about the Caring God, but in the latter they are much less popular. Finally, within mode, Aeolian and Mixolydian are less popular than Ionian, but in PKN and Iso the differences are small.

Doubt, stanzalength and foureighttwelve showed varying results. Doubt is a predictor of popularity in Iso and of unpopularity in GKv. Furthermore, foureighttwelve is a predictor of popularity in both denominations singing rhythmically, while stanzalength (not shortness) is a predictor of popularity in Iso.

As Table 8 shows, an additional regression on Psalmboek showed somewhat deviant results. In the first place the fixed effect for all the variables and the odds for all categories, even for $5+$, are highly significant $(\mathrm{p}<.001)$. However, unexpectedly, both repetition $_{\text {rhythm }}$

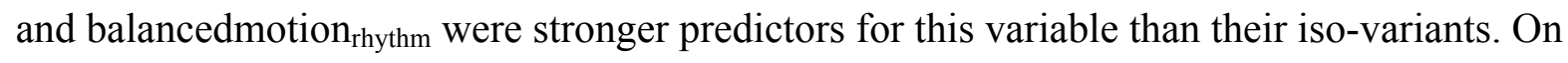
the other hand, the relatively low odds ratio for $6+$, and the relatively high odds ratio for $1^{\text {st }}$ Line, Ionic mode and Caring God are more in line with the patterns visible in Iso. 


\section{Discussion}

The results of Study II yield further support for our predictions concerning repetition and balancedmotion as predictors of psalm popularity. In the repeated measures regressions, both variables and most of their categories show significant effects, even in full models with mode, contents, and length. While some categories are not significant, the general finding falls in line with our predictions concerning the style of singing (see general discussion). The same holds for the fact that the additional variable concerning double balance (foureighttwelve) predicts popularity only in denominations singing rhythmically. In addition, the results for mode and contents confirm the findings of earlier research, although contents shows interesting differences between denominations.

An additional regression on the smaller but more exact dataset Psalmboek yielded a weaker model in terms of effect size, yet all categories were significant. The results of this regression are in line with our general predictions concerning repetition and balanced motion but not always with the specific predictions concerning the effect of singing isometrically. Overall, within balanced motion 5+ is still a problematic category, although it is a significant predictor for popularity in Psalmboek and not a signicant predictor of unpopularity for the other scales. Another point is that we have tested our predictions within the context of Dutch protestant denominations which has been very protective towards the Genevan psalms. This was expected to affect the effect of certain preference rules. Therefore, in Study III, we will test them within a less protective context.

\section{Study III}

\section{Introduction}


In the previous studies we tested our predictions concerning the effect of repetition and balancedmotion on psalm popularity within the context of the Dutch protestant tradition of psalm singing. However, as we have mentioned earlier, in other arenas, less protective towards the Genevan psalms and their melodies, the effects might be different. For example, melodies with Late repetitions might require enhanced exposure and therefore might not be able to survive the competition with other hymns, making it possible that early repetitions, shortness, and balancedmotion could be more important.

We will test our predictions using counts of Genevan melodies used for psalms or other hymns either in North America, in Germany, or in the low countries between the second half of the $16^{\text {th }}$ century and 1938 . As some of the Genevan melodies are used for more than one psalm (see Appendix I) it is often impossible to find out which psalm was used for a certain contrafact (i.e. new lyric), hence all occurrences of a certain melody are aggregated, which reduces our datasets from 150 to 125 ratings per count. As a result of this, the categorization of contents is of little value. However, as stanza form and rhyme scheme for contrafacts are stipulated in the melody (except when there are just male or female rhymes), this would be unlikely to affect the influence of repetition and balancedmotion.

\section{Method}

Repeated measures ordinal or Poisson log linear regressions were run on variables indicating the popularity of the Genevan melodies for contrafacts in three countries.

Independent variables - In this study we worked with mode, stanzalength, foureighttwelve, balancedmotion, and a new version of repetition, repetition $\mathrm{cf}_{\mathrm{c}}$, in which all the psalms in Late+ are added to Late- . However, due to quasi complete separations we had to create an additional version of balancedmotion (see Table 1 and Table 9) for one regression.

Dependent variables - Three DVs were created: 
CfIso is created by combining four different counts of Genevan melodies used for psalms or contrafacts in Dutch songbooks and hymnals in earlier ages, before the introduction of rhythmic singing (see Appendix IVb). The scales are combined in a similar way to the scales underlying PKN and Iso in Study II, allowing for repeated measures ordinal regressions.

America reflects the number of times Genevan Melodies are used in hymnals in North America either for contrafacts or for translations of Genevan Psalms, according to the website Hymnary.org. This score ranges from 0 (74 times) to 655 (once), with a mean 10.11 and SD 61.02, and a median of 0 .

Germany is based on the number of times Genevan Melodies are used in hymnals in non-Calvinist Germany before 2000, according to Leaver (2004) and Scheitler (2004). However, while Leaver provides clear lists supporting exact counts, Scheitler (investigating a different period) mentions simply that a psalm is used 'often' or for 2, 3 or 4 different contrafacts occurring in several hymnals. Here, we have counted the number of different contrafacts Scheitler mentions. Scales range from 0 (58 times) to 8 (once); Mean 0.99; SD 1.42; Median 1.

\section{Results}

A repeated measures ordinal regression with CfIso, and poisson log-linear regressions with America and Germany show varying results (see Table 9). While the regression with America shows clear significant effects for all variables, the predictive power of the models for CfIso and Germany is much weaker. Moreover, none of the CART regressions with these three variables resulted in a tree with a Relative error below 1. Even a tree predicting AAB, AA'B, long alternating, and Ionian mode to be relatively popular in Germany had a relative error of 1.3 , which means that the results are not reliable, although $R^{2}$ is .03 . 
In all cases stanzalength significantly predicts popularity (the shorter the more

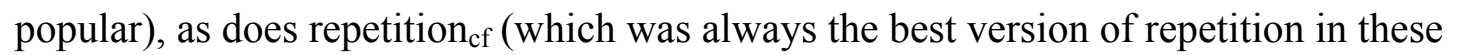
regressions). Finally, mode is a significant predictor only for America, but for Germany and CfIso the odds for Ionian are larger than those for Aeolian or Mixolydian, which in turn are larger than those for Dorian or Phrygian.

\section{Discussion}

The regressions in Study III are in line with our hypotheses concerning the effect of length and late repetitions on the popularity of Genevan psalms and melodies in non-protective contexts. Furthermore, repetitions of the first line, especially those which lead to an AAB or AA'B form, are relatively popular in these arenas. However, the models as a whole are much less powerful than those found in Studies I and II. For example, mode is not a significant predictor in all three models (although the odds show a similar pattern across all regressions). We will address these results in more detail in the General discussion.

\section{General Discussion}

The main aim of the three studies reported in this paper was to test the effects of several aspects of musical and poetic form which we suggest support processing fluency on the popularity of Genevan psalms. In order to do so, we created two multinomial variables in which each category represented a group of psalms with specific properties thought to affect popularity in a specific way. In the variable balancedmotion these properties concerned rhyme scheme, line length, number of lines per stanza, or the occurrence of a tonic at the end of a line halfway through the stanza, all in relation to balance, motion, and segmentation. In the variable repetition these properties concerned the occurrence of verbatim repetitions of melodic material, combined with the same kind of properties worked up in balancedmotion. 
We chose the case of the Genevan Psalms because they represent a small set of hymns from which just a few have been sung frequently through the ages, even though the Psalms are almost the only hymns that were allowed to be sung in Dutch protestant services for a long period of time.

We tested repetition and balancedmotion in regressions on dependent variables indicating the popularity of Genevan psalms and melodies in different arenas, distinguishing between denominations singing isometrically and denominations singing rhythmically. In Study I we tested our target variables separately, in Study II we tested them in regressions with several other variables, three of which were previously known to predict psalm popularity. Finally, we tested our target variables in full models on dependent variables representing the popularity of Genevan Melodies in three different countries.

The results provide support for most of our predictions concerning repetition and balancedmotion, although the support for some of them is stronger than for others. In the following sections we will discuss our findings and their possible origins.

Balancedmotion and length - Our predictions on balance, motion, and segmentation, laid down in a set of preference rules (see Pilot, discussion), were spread over three variables: balancedmotion, foureighttwelve, and repetition. In balancedmotion our categorization was based on the idea that the effect of several melodic and poetic features is dependent on the number of lines in a stanza, that some features are easier to perceive than others, and that isometric singing heightens the need for features supporting motion. Rhythmic singing (on the other hand) was hypothesized to induce motion and subsequently to give features accentuating balance the opportunity to become appreciated. Our findings support this idea.

Balancedmotion is a significant predictor in nearly all of our regressions, especially those in Study II with full models on the largest datasets. It is only in CART trees on relatively small datasets that balancedmotion does not act as a significant predictor. However, 
the significance of balancedmotion was sometimes somewhat compromised because all categories were always included, even in regressions where we would not expect them to have an effect. For example, 5+ sometimes significantly predicted unpopularity, therefore embellishing the $p$-value for balancedmotion, but in other cases $4+$ or Long+ does not show a significant effect, weakening our $p$-value even though the finding is in line with our predictions.

As expected, Long alternating and Long+ show significant effects in almost every regression, with a tendency for Long alternating to be more popular in denominations singing isometrically, and Long+ to be more popular in denominations singing rhythmically, although the results for Germany and Psalmboek are somewhat deviant. These results indicate that motion is very important in longer psalms, that motion can be created by an easily perceivable alternating rhyme scheme or by a delicate interplay between melody and more complex rhyme schemes, but that the alternating rhyme scheme might be more effective in isometric singing. Remarkably, this means that psalm singing requires a different rhyme scheme than oral story telling which benefits from paired rhyme schemes (Rubin, 1995).

Concerning six-line psalms, Tonic 3 turned out to show significant effects in most of the regressions except for those on the contrafact scales, while $6+$ is a relatively strong predictor for PKN and GKv, but not for iso-related scales. These results support our assumptions concerning the effect of style of singing, and the importance of segmentation for the popularity of six-line psalms, associated with the unbalanced number of lines.

The results for $4+$ show that four-line psalms with repeated rhythmic patterns containing caesuras or with an absolute minimum number of syllables are much more popular in communities singing rhythmically than in those singing isometrically, although the odds for this category are not significant in Germany, and the users of Psalmboek act like individuals singing rhythmically. The version of $4+$ based on the interaction between tonic 
placing and rhyme scheme is a significant predictor of Iso. A confounding factor might be that one of the psalms in $4+_{\text {rhythm, }}$ psalm 116 , which is very popular everywhere, is also an AAB-shaped psalm. As Table 3 shows, there are just a few four-line psalms relatively popular in Iso, therefore the popularity of 116 might have a relatively large effect on the results for $4+_{\text {rhythm. }}$

Nevertheless, it is clear that, in spite of their shortness, even the popularity of four-line stanza psalms is dependent on a delicate interaction between segmentation, balance, and motion. Furthermore, even these psalms seem to benefit from rhythmic singing. The results for $4+_{\text {rhythm, }}$ combined with those for $6+$ and foureighttwelve, which is a significant positive predictor of all rhythm-related scales (except Germany) but not for iso-related scales (except for a small effect in Psalmboek) are in line with our assumption that rhythmic singing induces motion and gives more psalms the opportunity to become popular, but only if they are correctly balanced.

An alternative explanation for the relative popularity of $4+_{\text {rhythm }}$ and $6+$ in denominations singing rhythmically might be that those denominations just prefer shorter psalms, or that denominations singing isometrically just prefer longer psalms. This would be in line with the results for stanzalength, and might be explained by the high level of devotion for which these denominations are known. However, the preference for longer psalms might also be related to the fact that in these denominations the communities sing more stanzas per psalm per service which might enhance the need for longer and more clearly segmented psalms (see the paragraph on Segmentation below). Furthermore, even this 'preference for longer stanzas' might be explained as representing a difficulty in perceiving motion in shorter ones, which is more in line with the relative popularity for Tonic 3 , the neutral version of $4+$ and, within repetition, $1^{\text {st }}$ Line in the same denominations. 
If denominations singing rhythmically do indeed prefer simple shortness, we would expect $5+$ to be more popular in rhythmic singing too, which is only true in America. These results are puzzling. They confirm the idea that people prefer a balanced number of lines unless the unbalance is somehow compensated, but it is unclear why this effect is not visible in Europe. It might be that our predictions concerning five-line psalms could be improved. For example, it would be theoretically appropriate to add five-line psalms in which the fourth line ends on the dominant to the 5+ category. Such a dominant might facilitate the delayed ending caused by the fifth line. A second explanation might be that contents play a part in the unpopularity of five-line-stanza psalms in Dutch services. Many five-line psalms are categorized as caring God psalms, but could also be categorized as negative ones on the basis of their contents.

Shortness does affect popularity in a positive way: long stanzas never consist of long lines; real shortness (measured in both metrical feet and type of rhyme) supports popularity in four-line psalms; and shortness (measured in metrical feet per stanza) is a significant predictor of the popularity of Genevan melodies for contrafact scales. However, we think that the results for balancedmotion show that in every song certain properties (motion, balance, and segmentation) are required, which sometimes might be more readily found in longer psalms.

Repetition - As hypothesized, verbatim melodic repetitions turned out to predict popularity in all countries and denominations. Within repetition, AAB is the most constant factor, although other categories are sometimes more popular, for example $1^{\text {st }}$ Line is relatively popular in denominations singing isometrically. Furthermore, late repetitions clearly require both a protective environment and motion, which is in line with the idea of an inverted U-shaped relationship between complexity and familiarity on the one hand, and aesthetic valence the other (Berlyne, 1971; North \& Hargreaves, 1995; Chmiel \& Schubert, 2017). While late psalms in general are not popular for contrafacts, Late + psalms are a relatively 
strong predictor for popularity in Dutch protestant services. Moreover, the differences

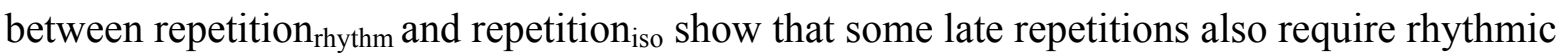
singing. Hence, the results for AAB, AA'B and Late+ confirm our assumption that motionsupported segmentation supports popularity. Furthermore, the results for $4+_{\text {rhythm }}$ indicate that rhythmic repetitions also support psalm popularity.

These findings are in line with the fact that repetitive forms such as the medieval Bar form (AAB), the da-capo aria (ABA) and the Tin-Pan-Alley standard (AABA) have proven to be appealing, that the sentence $(\mathrm{abc})$ is the prevalent strophic form in rock (Summach, 2012, p. 24), that repetition is an important predictor for song segments to become hooks (Van Balen, 2016), and that repetition in music enhances appreciation (Margulis, 2014, p. 15). As we have set forth earlier, an explanation for this effect is that repetition supports processing fluency (Huron, 2013). Additional explanations might be that repetition in music enhances (physical) engagement (Margulis, 2014b). Furthermore, repetitions support correct musical predictions which are known to activate the limbic reward system (Menon \& Levitin, 2005).

Segmentation - Segmentation plays a big part in creating balance and motion, but segmentation in itself (if supported by motion) also supports popularity, as demonstrated by the predictive power of $\mathrm{AAB}, \mathrm{AA}^{\prime} \mathrm{B}$, Late+, and Late- within repetition. The importance of segmentation could be explained in terms of memory support, and enhanced text processing by structuring both the music and the language of the psalm. This might also be explained in that it may prevent strophic songs from being boring or evoking a state of non-attentive trance (Huron, 2013). The issue with song is that language is less resistant to habituation than music (Margulis, 2014). Moreover, because repetitions of longer musical segments are relatively easy to recognize (Margulis, 2014), song sections (which are relatively long in general) may be particularly susceptible to habituation. This might explain why people are more aware of the bigger structure of songs than they are of the bigger structure of instrumental music 
(Rolison \& Edworthy, 2012; Tsai et al., 2014), and why they expect different kinds of repetition patterning to occur in song than they do in instrumental music (i.e. ABABpatterning, versus AAABBB-clustering) (Rolison \& Edworthy, 2012; Ollen \& Huron, 2004; Huron, 2013). Segmented psalms provide such an ABAB-patterning.

Isometric singing - As mentioned above, the results for the different versions of both repetition and balancedmotion confirm our predictions that some of the psalm properties that support popularity are difficult to perceive in isometric singing.

However, our prediction that repetition and balanced motion would be more important as predictors for psalm popularity in communities singing isometrically than in communities singing rhythmically was not unambiguously proven. That is to say, in the main repeated measures regressions in Study II, both repetition and balanced motion were far more important as predictors for Iso than contents. Furthermore, in Study I $R^{2}$ for repetition was larger in regressions for Iso-related scales than for rhythm-related scales. However, the Wald statistics for contents in the regression on Psalmboek in Study II suggest that contents might be more important than CARTs Rvis indicate.

Nevertheless, the introduction of rhythmic singing in the main Dutch protestant denominations in 1938 seems to have increased the propensity of several psalms to become popular, although at the same time the number of psalms sung per service decreased because of the introduction of other hymns. As Table 3 shows, in denominations singing Isometrically a few psalms have stayed popular through the ages, while in PKN the range is broader. The regressions on PKN and GKv show that shorter psalms, as well as more complex longer psalms such as 149 (see Appendix III), have become more popular.

Of course there might be other explanations for some of these differences. In the first instance, contents may explain some of them. The two variables of contents and doubt show significant content-related differences across the preferences of the various denominations. In 
GKv and PKN, psalms of praise are as popular as psalms about a caring God, while in denominations singing isometrically, psalms about a caring God are far more popular than psalms of praise. Furthermore, psalms of doubt are unpopular in GKv (which is in line with Werkman, 1992), while they are popular in denominations singing isometrically. These results are in line with the fact that contemporary denominations singing isometrically are known for stressing the personal relationship with God, while GKv-members, according to Werkman (1992), mainly sing to affirm their faith. Relying on the remarks of some of the informants from the $P K N$, the predictive strength of contents might be improved for PKN if every psalm that refers to 'the enemy' or to 'sin' or 'guilt' was added to the category negative psalms. For example, the five-line psalms with melodies that have become popular in America, now categorized as Caring-God psalms, would all move to that category.

Another factor that might have affected the popularity of certain psalms in denominations singing rhythmically is translation, as both PKN and GKv make use of new rhyming versions. For at least three of the psalms that are more popular in denominations singing rhythmically than in denominations singing isometrically, translation might also play a part. In psalm 149 (Wit, in ISK, 1973, see Appendix III), the translation of 1967 is the first official translation that follows the inverse metrics of the $5^{\text {th }}$ and $6^{\text {th }}$ line; Nijhof's translation of psalm 150 (ISK, 1973) is the first that supports the segmentation of the melody into a fiveline part and a three-line part, while the rhyme scheme indicates a four-four segmentation (aabbcddc); and Barnard (ISK, 1973) makes a unique iconic use of the rhythmic changes and pitch turns in the melody in his rhyming version of 121.

However, given the fact that the differences concerning the results for repetition and balancedmotion between denominations singing rhythmically or isometrically are also visible in regressions in which contents is taken into account, it seems reasonable to conclude that the style of singing affects psalm choice at least in part. These results shed new light on the 
ongoing debate in The Netherlands on the proper way to sing the Genevan psalms and the introduction of syncopated songs. The choice for slow isometric singing is often defended by arguing that singing rhythmically distracts attention from the words. As the Dutch organ player Kasper Jansen puts it: 'It starts with singing rhythmically, and it ends with 'tralala and upsadaisy' (Jansen, 2009; translation - YPS), connecting rhythmical singing to the introduction of evangelical hymns. Dutch protestants often seem to be afraid that people may become rapturous by rhythmical music and as a consequence fail to attend the words consciously. It is true that slow isometric singing eliminates several properties of composition and performance that communicate or evoke emotion (Quinto \& Thompson, 2013). However, it is not beyond dispute whether the result of incorporating rhythm this would lead to a change in the salience of the words. According to Rommeling, a seventeenth century minister, the Dutch way of singing psalms impairs intelligibility and understanding (Luth, 2004, p. 430). Furthermore, recent research indicates that a variable but somehow predictive rhythm activates cognitive processing, while mechanical timing does not (Nokata, 2016). Our results do not provide any evidence concerning attention to the words, but they do imply that isometric singing at least affects the accessibility of the contents of certain psalms.

Contrafacts - The results of Study III have confirmed our predictions concerning the effect of stanzalength and late repetitions for contrafacts. These results are in line with Reali et al. (2018) who hypothesize (based on linguistic research) that an increase in community size might be associated with a reduction in the prevalence of complex cultural expressions. Nevertheless, the models predicting contrafact-scales are relatively weak compared to those predicting psalm popularity in Dutch protestant communities. An explanation might be that the datasets in this study are too small to reveal clear significant results, as a consequence of the reduction from 150 psalms to 125 melodies, which also affects category size. Another explanation might be the wording of the rhyming versions in other languages, or the contents 
of the new hymns using Genevan melodies. Finally, historical circumstances might play a part, such as the fact that Psalm 134 fitted the meter in which the English rhyming version of the whole Psalter was written. Subsequently, the melody became widely known in the AngloSaxon world.

Mode - Although mode was introduced as a control variable, to assess the power of repetition and balanced motion, within the context of this paper, it deserves some attention in itself. Nearly all regressions significantly confirm the predictions of Kats and Smelik who suggest that Ionian, Aeolian, and Mixolydian modes would be relatively popular because these modes sound familiar to ears used to Major and Minor scales, and indeed there is a connection between familiarity, processing fluency, and liking (Van Balen, 2016; Huron, 2013). Nevertheless, it is not certain whether the preference for these modes is really based on familiarity, as it is visible as early as 1606 (Marti, 2004) (when the change in tonal system was far from complete) and furthermore, even in our times the diatonic modes have been used quite regularly in folk and rock music (Temperley \& De Clerq, 2013; Moore, 1992; Powers et al., 2001). As the Ionian mode is perceived as happy (Temperley \& Tan, 2013), an alternative explanation for its popularity would be that Calvinist protestants prefer happy music. This would be in line with their aversion to negative contents. However, the Dorian mode is perceived as happier than the Aeolian mode (Temperley \& Tan, 2013) but it is both less popular and less familiar, at least nowadays (Tan \& Temperley, 2015). Another indication that mode preferences have something to do with processing fluency is that the minor mode is considered to be of greater complexity than the major mode (Bonetti \& Costa, 2016).

\section{Conclusions and Limitations}

The results of the three current studies indicate that processing fluency is an important but complex factor predicting the popularity of songs or melodies. Interactions between 
aspects of poetic form and musical form that are thought to support processing fluency (such as melodic repetition, rhyme scheme, and stanza form) significantly predict psalm popularity in different arenas, even in models which include other significant factors such as contents and mode. Of course there will be other factors that influence local, individual, or temporary preferences (such as translations, theological points of view, ritual practices or the social acceptability of a word like 'Zion'), but given the predictive power of our variables, across all different datasets, we think that it is likely that the interaction between music and lyrics in the creation of segmentation, balance, and motion is also an important factor.

Our predictions concerning these interactions related specifically to psalms. However, the set of preference rules underlying them could be applied in a broader context. For example, repetitions within choruses might not be perceived as Late- repetitions because they occur at the beginning of a new song part, usually preceded by some musical tension anticipating it (Summach, 2012). Furthermore, the results of this study suggest that sometimes a relatively complex form might be easier to process than a relatively simple one, or at least that processing fluency might explain why certain complex forms are appreciated in spite of their complexity, while others are not. To equilibrate segmentation, balance, motion, habituation, and trance avoidance, relatively complex elaborate forms seem to be more effective than simple ones, although sometimes these more elaborate forms require a certain level of exposure. These findings support and amplify existing theories on metrics, processing fluency, repetition in music, song forms, and aesthetics, and serve new insights in the aesthetics of song lyrics and the craft of lyric writing.

Of course, further research is required: this is a regression study (not an experimental one), concerning only one set of songs specifically meant for community singing. Dependent and independent variables could be added or improved, and several theories are presented or tested for the first time and need further development and testing. 
Concerning the psalms, additional data are needed to improve the charts for PKN, GKv, and Iso, in order make them truly comparable to one other, and to create charts for the orthodox part of the PKN, for contrafacts used in denominations singing rhythmically, and for the popularity of the Genevan Psalter in countries like Hungary, Japan, and South-Korea, as well as in the Roman Catholic church.

Concerning the predictors, within balancedmotion several categories might be further improved. Furthermore, mode might be improved with information concerning modulations caused by fixed ficta; and contents by adding all psalms on enemies, sin, and guilt to the third category. New predictors might be created by using existing models measuring the complexity of melodies, such as the Expectancy-based model of melodic complexity created by Eerola and North (2000), or by highlighting other than verbatim melodic repetitions.

Aside from the psalms themselves, our set of preference rules should be tested on other datasets. Moreover, several related phenomena require further investigation. These include: the influence of repetition and segmentation on memory by comparing memory for first lines and first lines of B-parts of the same songs (such as psalm 149 and 122), or by further analyzing the hooks Van Balen (2016) found; the structure of stanzas and songs concerning repetitions (verbatim or not) and the way structure affects meaning; and the effect of singing isometrically, or using syncopated melodies, on attention to the lyrics.

By investigating the interaction between language and music in the Genevan Psalter, and providing evidence for several promising theories, this study contributes not only to the study of liturgical music, but also of language cognition, music cognition, poetics, aesthetics, song writing and multimedia communication.

\section{References}


Arleo, A. (2006) Do children's rhymes reveal universal metrical patterns? In: P. Hunt, Children's literature: Critical Concepts in Literary and Cultural Studies, vol IV, (pp39-56). Routledge.

Aroui, J.-L. (2009). Proposals for metrical typology. J.-L. Aroui \& A. Arleo (Ed.) Towards a typology of Poetic Forms: From language to metrics and beyond, (pp1-40). Amsterdam/Philadelphia: John Benjamin’s Publishing company.

Bakker, S. (1994) Psalter tonen op de scena. Geneefse melodieën bij auteurs van Nederlandstalig Renaissancedrama ca. 1567-1619. Groningen (unpublished).

Balen, J.M.H. van, (2016). Audio Description and Corpus Analysis of Popular Music. [Doctoral thesis.] Utrecht, 2016.

Beelen, H. (2004) “Braeve lieflijkckheidt”, “helderheidt van snaeren”, “deftig singhen”: Pieter Cornesiszoon Hooft als Psalmendichter. In Grunewald, E., H.P. Jürgens en J.R. Luth, Der Genfer Psalter und Seine Rezeption in Deutschland, der Schweiz und den Niederländen: 16.-18. Jahrhundert. (pp461-470). Tübingen: Max Niemeyer Verlag. Berlyne, D.E. (1971) Aesthetics and psychobiology. New York, NY: Appleton-CenturyCrofts.

Bonetti, L. \& Costa, M. (2016) Intelligence and Musical Mode Preference. Empirical Studies of the Arts, 34(2), 160-176. doi:10.1177/0276237416628907.

Bornstein, R. F. \& D’Agostino, P.R. (1994). The Attribution and Discounting of Perceptual Fluency: Preliminary Tests of a Perceptual Fluency/Attributional Model of the Mere Exposure Effect. Social Cognition 12 (2): 103-128.

Bosch, R.A. (1996), En nooit meer oude Psalmen zingen. Zingend geloven in een nieuwe tijd 1760-1810. Zoetermeer.

Breiman, L., Friedman, J., Stone, C.J. \& Olshen, R.A. (1984) Classification And Regression Trees. Taylor \& Francis. 
Chmiel, A \& Schubert, E. (2017) Back to the inverted-U for music preference: A review of the literature. Psychology of Music, 2017, 45(6), 886-909. DOI: $10.1177 / 0305735617697507$.

Cronbach, L. J. (1951). Coefficient alpha and the internal structure of tests. Psychometrika, 16(3), 297-334.

Curtis, M. E., Paroo, K. I., Holcomb, P. J. \& Bharucha, J. J. (2005). Music influences the processing of syntax. Poster presented at the annual conference of the Cognitive Neuroscience Society, New York, NY.

Drake, C. \& Palmer, C. (1993). Accent Structures in Music Performance. Music Perception, 10, 343-378. doi:10.2307/40285574.

Eerola, T. \& North, A. C. (2000). Expectancy-based model of melodic complexity. In Woods, C., Luck, G. B., Brochard, R., O'Neill, S. A. \& Sloboda, J. A. Keele: Proceedings of the Sixth International Conference on Music Perception and Cognition. Staffordshire, UK: Department of Psychology, Keele University. 1177-1183.

Gunning J. Hzn., J. H. (1910) De gezangenkwestie in de Nederd.Herv. Kerk., Utrecht.

't Hart, W. (2012) Zulks zingt dat volk niet, een onderzoek naar onbekende psalmen binnen de Hersteld Hervormde Kerk, Amsterdam, BA-thesis: Vrije Universiteit.

Huron, D. (2006) Sweet anticipation: Music and the psychology of expectation. Camrbidge, MA/London, UK: MIT.

Huron, D. (2013). A Psychological Approach to Musical Form: The Habituation-Fluency Theory of Repetition. Current Musicology, 96, 7-35. doi:10.71916/D8KP81FG. Interkerkelijke Stichting voor het Kerklied (ISK) (1973) Liedboek voor de kerken. 'sGravenhage/ Leewarden: Boekencentrum/Jongbloed-ZETKA.

Jansen, K. (2009) De lofzang klimt uit Sions zalen: De traditie van psalmen zingen op hele noten. NRC, 15th May 2009). 
Kamp, W. van der, (1972) Psalm 140 [English rhyming version]. Retrieved from: http://www.genevanpsalter.com/attachments/GenPs140_vanderKamp.HTM.

Kats, J. (1899) 'Poëzie en melodie bij ons kerkgezang', SWV 36, 563-588.

Kirby-Smith, H.T. (1999) The Celestial Twins: Poetry and Music Through the Ages. Amherst: University of Massachusets Press, 1999.

Kloppenburg, W. (1991) 'Psalmlied en volkslied, in: J. de Bruijn \& W. Heijting (red.), Psalmzingen in de Nederlanden van de zestiende eeuw tot heden, (pp233-244). Kampen.

Koyzis, D.T. (2014) Psalm 134 [English rhyming version]. Retrieved from: http://genevanpsalter.redeemer.ca/index.html.

Kruskal, W. H., \& Wallis, W. A. (1952). Use of ranks in one-criterion variance analysis. Journal of the American statistical Association, 47(260), 583-621.

Leaver, R.A. (2004) Genevan Psalm Tunes in the Lutheran Chorale Tradition. In Grunewald, E., H.P. Jürgens en J.R. Luth, Der Genfer Psalter und Seine Rezeption in Deutschland, der Schweiz und den Niederländen: 16.-18. Jahrhundert, (pp145-168), Tübingen: Max Niemeyer Verlag.

Luth, J. R. (1986), 'Daer wert om 't seerste uytgekreten ... ': Bijdragen tot een geschiedenis van de gemeentezang in het Nederlandse Gereformeerde protestantisme \pm 1550 \pm 1852 [Doctoral thesis]. Kampen, Uitgeverij Van den Berg.

Luth, J. R. (2004), Gemeindegesang in den Niederlanden im 16. Jahrhundert. In Grunewald, E., H.P. Jürgens en J.R. Luth, Der Genfer Psalter und Seine Rezeption in Deutschland, der Schweiz und den Niederländen: 16.-18. Jahrhundert, (pp421-434). Tübingen: Max Niemeyer Verlag.

Margulis, E. H. (2014). On repeat: How Music Plays the Mind. New York, NY: Oxford University Press. 
Margulis, E.H. (2014b). Verbatim Repetition and Musical Engagement. Psychomusocology: Music, Mind, and Brain, 24(2), 157-163..

Marti, A. (2004) Die Rezeption des Genfer Psalters in der deutschsprachigen Schweiz. In Grunewald, E., H.P. Jürgens en J.R. Luth, Der Genfer Psalter und Seine Rezeption in Deutschland, der Schweiz und den Niederländen: 16.-18. Jahrhundert, (pp359-369). Tübingen: Max Niemeyer Verlag.

Meijer, J. (2004) De Heere, Datheen and Manix. Three Dutch versifiers of the Genevan Psalter. In Grunewald, E., H.P. Jürgens en J.R. Luth, Der Genfer Psalter und Seine Rezeption in Deutschland, der Schweiz und den Niederländen: 16.-18. Jahrhundert, (pp435-446). Tübingen: Max Niemeyer Verlag.

Moore, A. (1992) Patterns of Harmony. Popular Music, 11, 73-106.

Menon, V. \& Levitin, D. (2005). The rewards of music listening - Response and physiological connectivity of the mesolimbic system. NeuroImage, 28, 175-184. doi:10.1016/j.neuroimage.2005.05.053.

Naudin, M. (1968), Evolution parallelle de la poésie et de la musique en France: Rôle de unificateur de la chanson. Paris: NIZET.

Neath, N. \& Brown, G.D.A. (2006) SIMPLE: Further applications of a Local Distinctiveness Model of Memory. In B.H. Ross, The Psychology of Learning and Motivation: Advances in Research and Theory 46, (pp245-287), San Diego/London: Academic Press.

Nokata, T. (2016). Mechanical Timing Enhances Sensory Motor Processing Whereas Expressive Timing Enhances Later Cognitive Processing. Poster presented at the $14^{\text {th }}$ International Conference on Music Perception and Cognition, San Francisco.

North, A.C. \& Hargreaves, D.J. (1995) Subjective complexit.y, familiarity and liking for popular music. Psychomusicology, 14(1-2), 77-93. 
Ollen, J. \& Huron, D. (2004). Listener Preferences and Early Repetition in Musical Form. In S. D. Lipscomb, R. Ashley, R. O. Gjerdingen \& P. Webster (eds.) Proceedings of the $8^{\text {th }}$ International Conference on Music Perception and Cognition, pp405-407. Evanston, (Ill.): Casual Productions.

Pattison, P. (2009). Writing better lyrics: the essential guide to powerful songwriting. Cincinatti: Writer's Digest Books.

Peretz, I., Radeau, M. \& Arguin, M. (2004) Two-way interactions between music and language: Evidence from priming recognition of tune and lyrics in familiar songs. Memory \& Cognition, 32(1):142-52.

Polder, J., (2001). Een bekend lied. Zingen op zondag in de Gereformeerde Gezindte. Kerk \& muziek. VOGG.

Pollmann, J. (1965), Over de populariteit van Datheen's psalmberijming, Gregoriusblad, 87.

Powers, H.S., Porter, J. \& Cowdery, J. (2001, renewed 2012) Mode, IV: Modal Scales and Traditional Music. In Grove Music Online. Retrieved from: http://www.oxfordmusiconline.com.proxy.lybrary.uu.nl/subscriber/article/grove/music /43718pg4" \1 "S43718.4.

Quinto, L. \& Thompson, W.F. (2013) Composers and Performers have Different Capacities to Manipulate Arousal and Valence. Psychomusicology: Music, Mind and Brain, 23(3), 137-150.

Reali, F., Chater, N. \& Christiansen, M. H. (2018) Simpler grammar, larger vocabulary: How population size affects language. Proceedings of the Royal Society B. Biological sciences. 285. 20172586.

Rolison, J. \& Edworthy, J. (2013) The Whole Song Is Greater Than the Sum of Its Parts: Local and Structural Features in Music Listening. Psychomusocology: Music, Mind, and Brain, 23(1), 33-48. doi:10.1037/aoo32442. 
Rubin, (1995). Memory in oral traditions. The cognitive psychology of epic, ballads, and counting-out rhymes. New York, NY: Oxford University Press.

Scheitler, I. (2004), Der Genfer Psalter im protestantischen Deutschland des 17. und 18. Jahrhunderts. In Grunewald, E., H.P. Jürgens en J.R. Luth, Der Genfer Psalter und Seine Rezeption in Deutschland, der Schweiz und den Niederländen: 16.-18. Jahrhundert, (pp263-282). Tübingen: Max Niemeyer Verlag.

Schenkeveld-van der Dussen, M. A. (2004) The Hugenot Psalter in the Dutch Republic. The Functions of Rhymed Psalm Versions in the Seventeenth Century. In Grunewald, E., H.P. Jürgens en J.R. Luth, Der Genfer Psalter und Seine Rezeption in Deutschland, der Schweiz und den Niederländen: 16.-18. Jahrhundert, (pp447-460). Tübingen: Max Niemeyer Verlag.

Schotanus, Y. P. (2007). Song- en liedteksten schrijven: van cabaret tot rock, Amsterdam: Augustus

Schotanus, Y.P. (2015) The Musical Foregrounding Hypothesis. How Music Influences the Perception of Sung Language. In Ginsborg, J., Lamont, A., Philips, M. \& Bramley, S. (Eds.), Proceedings of the Ninth Triennial Conference of the European Society for the Cognitive Sciences of Music, 17-22 August 2015, Manchester, UK.

Smelik, J. (1997), Eén in lied en leven: Het stichtelijk lied bij Nederlandse protestanten tussen 1866 en 1938. (Doctoral thesis), Groningen: Sdu Uitgevers, IJkpunt 1900, Nederlandse Cultuur in Europese Context.

Tan, D., Temperley, D. (2017) Perception and Familiarity of Diatonic Modes. Music Perception: An Interdisciplinary Journal, 34(3), 352365. doi:10.1525/MP.2017.34.3.352.

Temperley, D. (2001) The Cognition of Basic Musical Structures. Campbridge, MA/London, UK: MIT. 
Temperley, D., \& Tan, D. (2013) Emotional connotations of diatonic modes. Music Perception, 30, 237-57. doi:10.1525/MP.2012.30.3.237

Temperley, D. \& Clerq, T. de (2013) Statistical Analysis of Harmony and Melody in Rock Music. Music Perception, 42(3) 187-204. doi:10.1080/09298215.2013.788039.

Tsai, C.-G., Chen R.-S. \& Tsai, T.-Z. (2014). The arousing and cathartic effects of popular heartbreak songs as revealed in the physiological responses of listeners. Musicae Scientiae, 18(4), 410-422. doi:10.1177/1029864914542671.

Werkman, H.N. (1991) Wij zijn in uw ontferming: Zingen op een eiland, Nederlands Dagblad, 28 december 1991, Variant, 4.

Werkman, H.N. (1992) Roepend om gehoor te vinden, om bij God gehoor te vinden, Nederlands Dagblad, 4 januari 1992, Variant, 4.

Winn, J.A. (1981), Unsuspected Eloquence. A History of the Relation between Poetry and Music, New Haven, Connecticut: Yale University Press. 


\section{Table 1.}

Independent variables and their levels in Study I, II and III,.

\begin{tabular}{|c|c|c|c|c|c|c|c|}
\hline Variable & Level & & & & & & \\
\hline Categorical & 0 & 1 & 2 & 3 & 4 & 5 & 6 \\
\hline \multicolumn{8}{|l|}{ Study I \& II } \\
\hline Repetition $^{2}$ & Late - & No repetition & Late+ & $1^{\text {st }}$ Line & $A A^{\prime} B$ & $A A B$ & \\
\hline Balancedmotion $^{3}$ & No bal.motion & $6+$ & Long alternating & Long+ & $4+$ & $5+$ & Tonic 3 \\
\hline \multicolumn{8}{|l|}{ Study II \& III } \\
\hline Mode & Dorian/Phrygian & Aeolian/Mixolydian & Ionian & & & & \\
\hline Contents & Negative psalms & Psalms of praise & Caring God & & & & \\
\hline Doubt & No doubt & Doubt & & & & & \\
\hline \multirow[t]{2}{*}{$4-8-12^{5}$} & $5,6,7,9$, or 10 & 4,8 or 12 lines per & & & & & \\
\hline & lines per stanza & stanza & & & & & \\
\hline \multicolumn{8}{|l|}{ Study III } \\
\hline Repetition $_{\mathrm{cf}}$ & Late & No repetition & & $1^{\text {st }}$ Line & $A A^{\prime} B$ & $A A B$ & \\
\hline Balancedmotion $_{\mathrm{cf}}$ & Other & & Long alternating & Long+ & $4+$ & & Tonic 3 \\
\hline Numerical & Lowest value & Highest value & & & & & \\
\hline \multicolumn{8}{|l|}{ Study II \& III } \\
\hline Stanzalength & 16 feet per stanza & 48 feet per stanza & & & & & \\
\hline
\end{tabular}

${ }^{1}$ In general level 0 is thought to be unpopular, for Doubt it depends on the denomination;

${ }^{2}$ We just provide category-levels, for an explanation of the contents we refer to the introduction of the IVs in the text.

${ }^{2}$ Repetition was used in two variants, in repetititon rhythm $_{23,} 29$ and 149 are in Late+, 61 in Late-, in repetition iso $_{\text {o }}$ this is the other way around.

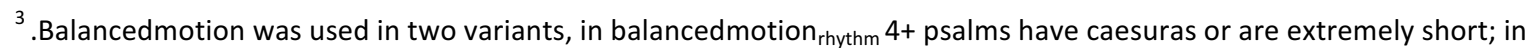
balancedmotion $_{\text {iso }} 4+$ psalms have either paired rhyme and no tonic at the end of the second line, or another rhyme scheme plus a tonic at the end of the second line. 
Table 2.

Scale construction Iso, PKN and underlying scales (see also Appendix IVa \& V)

\begin{tabular}{|c|c|c|c|c|c|c|c|c|c|}
\hline \multirow[t]{2}{*}{ ISO scale } & \multicolumn{2}{|c|}{ Categories } & \multirow[b]{2}{*}{2} & \multirow[b]{2}{*}{3} & \multirow[t]{2}{*}{ PKN scale } & \multicolumn{2}{|c|}{ Categories } & \multirow[b]{2}{*}{2} & \multirow[b]{2}{*}{3} \\
\hline & 0 & 1 & & & & 0 & 1 & & \\
\hline Hymnals 1866-1938 & 120 & 0 & 23 & 7 & Organ player1 (recent use) & 137 & 0 & 3 & 10 \\
\hline Diaries +/- 1900 & 139 & 0 & 0 & 11 & Minister1 (use during career) & 99 & 0 & 24 & 27 \\
\hline Rotterdam 1864-1889 & 130 & 0 & 7 & 13 & Minister2 (use during career) & 101 & 0 & 18 & 31 \\
\hline Kampen +/- 1900 & 134 & 0 & 0 & 17 & Minister3 (2011-15) & 123 & 0 & 15 & 12 \\
\hline Delfshaven 1903-1909 & 134 & 0 & 10 & 9 & Minister4 (recent use) & 146 & 0 & 0 & 4 \\
\hline 13 Churches 2000-2001 & 42 & 33 & 45 & 30 & Organ player2 (1960-90) & 139 & 0 & 0 & 21 \\
\hline \multirow[t]{2}{*}{ Several churches 2012} & 36 & 43 & 43 & 28 & Minister5 (use during career) & 31 & 42 & 45 & 32 \\
\hline & & 76 & 128 & 101 & & & 42 & 105 & 137 \\
\hline ISO & 24 & 90 & 17 & 19 & PKN & 27 & 80 & 31 & 12 \\
\hline
\end{tabular}


Table 3.

Distribution of psalms over categories of repetition, balancedmotion repetition and the

highest categories of the dependent variables

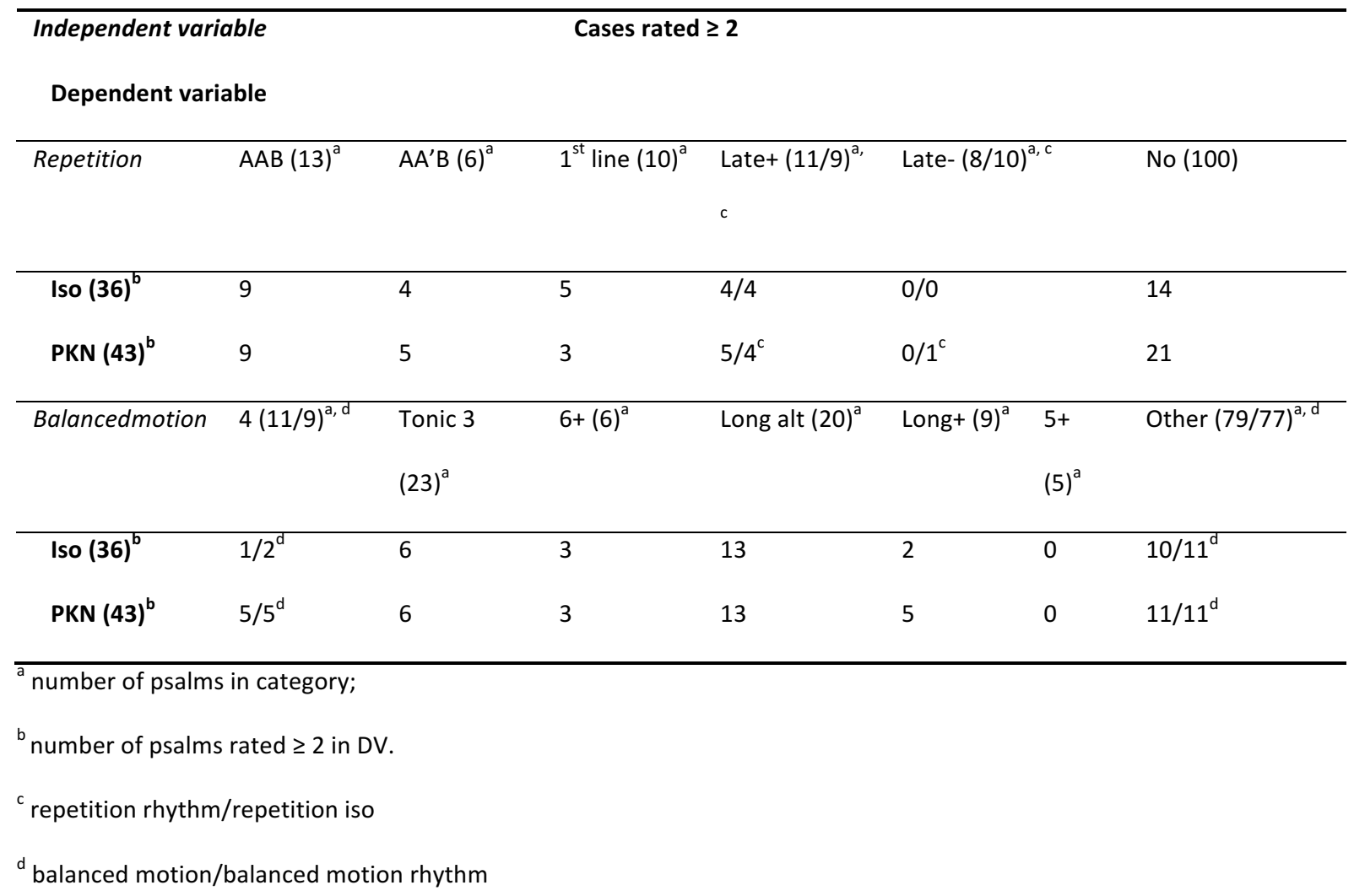


Table 4.

Ordinal logistic and CART regressions with repetition on PKN and Iso.

\begin{tabular}{|c|c|c|c|c|c|c|}
\hline & \multicolumn{2}{|l|}{ PKN } & \multicolumn{4}{|l|}{ Iso } \\
\hline & \multicolumn{2}{|c|}{ Repetition Rhythm } & \multicolumn{2}{|c|}{ Repetition Rhythm } & \multicolumn{2}{|c|}{ Repetition Iso } \\
\hline $\mathrm{GoF}^{\mathrm{a}}$ & \multicolumn{2}{|l|}{$\mathrm{v}$} & \multicolumn{2}{|l|}{$\mathrm{v}$} & \multicolumn{2}{|l|}{$\mathrm{v}$} \\
\hline$p$ ToP $^{b}$ & \multicolumn{2}{|l|}{.32} & \multicolumn{2}{|l|}{.59} & \multicolumn{2}{|l|}{.56} \\
\hline Wald $\chi^{2 c}$ & \multicolumn{2}{|l|}{$24.12^{* * *}$} & \multicolumn{2}{|l|}{$32.44^{* * *}$} & \multicolumn{2}{|l|}{$33.15^{* * *}$} \\
\hline$R^{2}$ SPSS & \multicolumn{2}{|l|}{.17} & \multicolumn{2}{|l|}{.24} & \multicolumn{2}{|l|}{.24} \\
\hline $\mathrm{R}^{2}$ learn CART & \multicolumn{2}{|l|}{.16} & \multicolumn{2}{|l|}{.21} & \multicolumn{2}{|l|}{.23} \\
\hline $\mathrm{R}^{2}$ test CART & \multicolumn{2}{|l|}{.11} & \multicolumn{2}{|l|}{.18} & \multicolumn{2}{|l|}{.22} \\
\hline Rel. error CART & \multicolumn{2}{|l|}{.89} & \multicolumn{2}{|l|}{.83} & \multicolumn{2}{|l|}{.79} \\
\hline Category & $\operatorname{Exp}(B)^{d}$ & $95 \% \mathrm{Cl}$ & $\operatorname{Exp}(B)^{d}$ & $95 \% \mathrm{Cl}$ & $\operatorname{Exp}(B)^{d}$ & $95 \% \mathrm{Cl}$ \\
\hline AAB & $15.79 * * *$ & 3.37- 73.87 & $34.48^{* * *}$ & $6.46-184.02$ & $30.25^{* * *}$ & $6.03-151.66$ \\
\hline$A A^{\prime} B$ & $20.18^{* *}$ & $3.34-121.98$ & $16.58^{* *}$ & $2.65-103.77$ & $14.50 * *$ & $2.45-85.70$ \\
\hline $1^{\text {st }}$ line & $5.75^{*}$ & $1.13-29.29$ & $14,74^{* *}$ & 2.71- 80.19 & $12.88 * *$ & $2.52-65.86$ \\
\hline Late + & $7.14 *$ & $1.41-36.18$ & $9.84 *$ & 1.81- 53.19 & $11.80 * *$ & $2.13-65.41$ \\
\hline No rep. & 2.06 & $0.65-\quad 6.57$ & 2.01 & $0.59-\quad 6.87$ & 1.74 & $0.56-\quad 5.47$ \\
\hline Late - & 1 & & 1 & & 1 & \\
\hline \multicolumn{7}{|c|}{${ }^{b} p$-value Test of Parallel lines } \\
\hline \multicolumn{7}{|c|}{${ }^{\mathrm{c}}$ Wald test statistic, comparable to $t$ in linear regressions; $\chi^{2}=(b / S E)^{2}$} \\
\hline
\end{tabular}


Table 5.

Poisson-logistic regressions using GZLM with repetition on Psalmboek

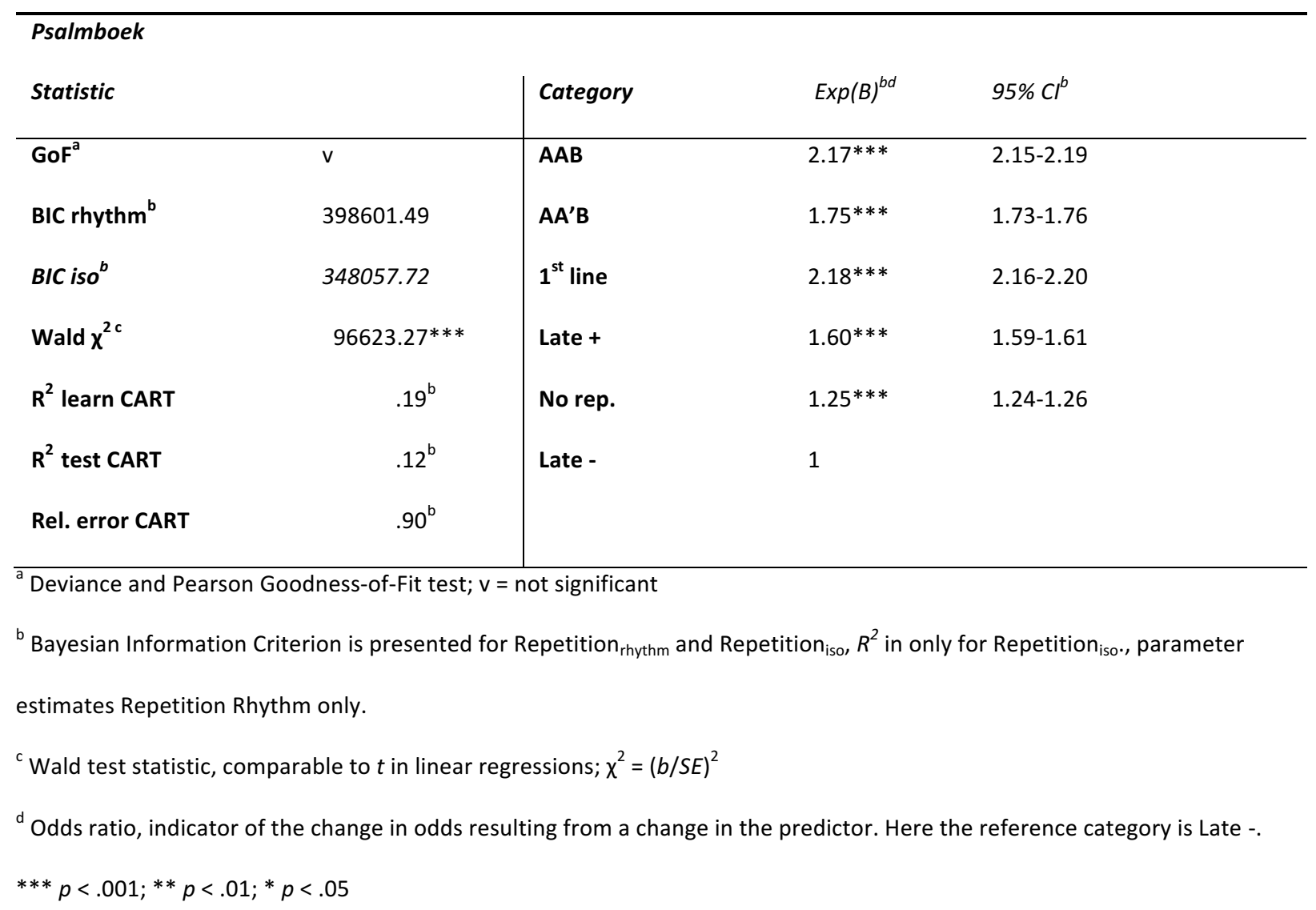


Table 6.

Poisson log-linear and CART regressions with balancedmotion on Psalmboek

\begin{tabular}{|c|c|c|c|c|}
\hline \multicolumn{5}{|l|}{ Psalmboek } \\
\hline \multicolumn{2}{|l|}{ Statistic } & \multirow{2}{*}{$\begin{array}{l}\text { Category } \\
\text { Long alternating }\end{array}$} & \multirow{2}{*}{\begin{tabular}{|l}
$\operatorname{Exp}(B)^{d}$ \\
$1.54^{* * *}$
\end{tabular}} & \multirow{2}{*}{$\begin{array}{l}95 \% \mathrm{Cl} \\
1.53-1.54\end{array}$} \\
\hline $\mathrm{GoF}^{\mathrm{a}}$ & $\mathrm{V}$ & & & \\
\hline BIC BM rhythm & 393403.57 & Long + & $1.14^{* * *}$ & $1.13-1.14$ \\
\hline BIC BM Iso & 387759.91 & 6-7 tonic 3 & $1.62^{* * *}$ & $1.61-1.64$ \\
\hline Wald $\chi^{2 c}$ & $59272.17^{* * *}$ & $6+$ & $1.15^{* * *}$ & $1.15-1.16$ \\
\hline $\mathrm{R}^{2}$ learn CART & $.09^{b}$ & $4+$ & $1.38^{* * *}$ & $1.37-1.38$ \\
\hline$R^{2}$ test CART & $.04^{\mathrm{b}}$ & $5+$ & $0.84 * * *$ & $0.83-0.85$ \\
\hline Rel. error CART & $.98^{\mathrm{b}}$ & Other & 1 & \\
\hline \multicolumn{5}{|c|}{ a Deviance and Pearson Goodness-of-Fit test; $v=$ not significant } \\
\hline \multicolumn{5}{|c|}{${ }^{\mathrm{b}}$ The results for balancedmotion ${ }_{\text {rhythm }}$ are reported, $R^{2}$ test for balancedmotion ${ }_{\text {iso }}$ is .02 , relative error is .99 . } \\
\hline \multicolumn{5}{|c|}{${ }^{c}$ Wald test statistic, comparable to $t$ in linear regressions; $\chi^{2}=(b / S E)^{2}$} \\
\hline
\end{tabular}


Table 7

Repetition, Contents, Mode, Motion, and Stanza length as predictors of popularity of

Genevan Psalms and tunes in different countries and denominations. The results of a series of cumulative odds ordinal logistic regressions, using GZLM.

\begin{tabular}{|c|c|c|c|c|c|c|}
\hline & $\begin{array}{l}\text { ISO }^{\mathbf{a}} \\
\text { SPSS }\end{array}$ & CART & $\begin{array}{l}\mathbf{P K N}^{\mathrm{a}} \\
\text { SPSS }\end{array}$ & CART & $\begin{array}{l}\mathbf{G K v}^{\mathbf{a}} \\
\text { SPSS }\end{array}$ & CART \\
\hline$N_{\text {valid }}$ & 397 & & 539 & & 9203 & \\
\hline Nodes $^{b}$ & & 41 & & 29 & & 68 \\
\hline$R_{\text {learn }}^{2}$ & & .62 & & .43 & & .21 \\
\hline$R_{\text {test }}^{2}{ }^{\mathrm{c}}$ & & .52 & & .32 & & .20 \\
\hline Type III/Rvi ${ }^{d}$ & Wald $\chi_{\text {factor }}^{2}$ & $\mathrm{Rvi}^{\mathrm{d}}$ & Wald $\chi_{\text {factor }}^{2}$ & $\mathrm{Rvi}^{\mathrm{d}}$ & Wald $\chi_{\text {factor }}^{e}$ & $\mathrm{Rvi}^{\mathrm{d}}$ \\
\hline Repetition & $52020.36(3)^{* * *}$ & 100 & $386.31(2)^{* * *}$ & 68.53 & $94.81(5)^{* * *}$ & 52.90 \\
\hline Contents & $136.02(2)^{* * *}$ & 62.97 & $185.41(2)^{* * *}$ & 100 & $98.46(2)^{* * *}$ & 100 \\
\hline Mode & $11.68(2)^{* *}$ & 66.05 & $18.78(2)^{* * *}$ & 32.36 & $105.89(2)^{* * *}$ & 39.59 \\
\hline Balancedmotion & $6360.14(6)^{* * *}$ & 81.51 & $91.67(6)^{* * *}$ & 91.13 & $105.54(6)^{* * *}$ & 47.42 \\
\hline Stanza length & $23.37(1)^{* * *}$ & f & $1.28(1)$ & $\mathrm{f}$ & $1.33(1)$ & f \\
\hline Foureighttwelve & 0.01 & $\dagger$ & $4.46(1)^{*}$ & 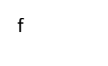 & $5.79(1)^{*}$ & 8.03 \\
\hline Doubt & $84.28(1)^{* * *}$ & 37.69 & $1.57(1)$ & 37.69 & $22.92(1)^{* * *}$ & 20.34 \\
\hline Estimates & $\operatorname{Exp}(B)^{g}(C I)$ & & $\operatorname{Exp}(B)^{g}(C I)$ & & $\operatorname{Exp}(B)^{g}(C I)$ & \\
\hline \multicolumn{7}{|l|}{ Repetition } \\
\hline AAB & $8.34(4.42-15.93)^{* * *}$ & & $5.98(2.94-12.17)^{* * *}$ & & $2.87(2.24-3.67)^{* * *}$ & \\
\hline$A A^{\prime} B$ & $6.92(4.58-10.44)^{* * *}$ & & $7.16(2.80-18.30)^{* * *}$ & & $2.00(1.60-2.50)^{* * *}$ & \\
\hline $1^{\text {st }}$ line & $19.08(11.11-32.76)^{* * *}$ & & $4.03(1.45-11.20)^{* *}$ & & $2.11(1.76-2.54)^{* * *}$ & \\
\hline Late + & $18.57(13.50-25.54)^{* * *}$ & & $6.14(3.55-10.62)^{* * *}$ & & $2.48(2.03-3.04)^{* * *}$ & \\
\hline No rep. & $4.04(3.34-4.90)^{* * *}$ & & $1.92(.92-3.98)$ & & $1.56(1.38-1.77)^{* * *}$ & \\
\hline Late - & 1 & & 1 & & 1 & \\
\hline \multicolumn{7}{|l|}{ Contents } \\
\hline Caring God & $8.62(5.93-12.53)^{* * *}$ & & $4.27(3.42-5.32)^{* * *}$ & & $2.93(2.37-3.63)^{* * *}$ & \\
\hline Praise & $3.54(2.79-4.50)^{* * *}$ & & $4.02(2.79-5.80)^{* * *}$ & & $3.00(2.40-3.77)^{* * *}$ & \\
\hline
\end{tabular}




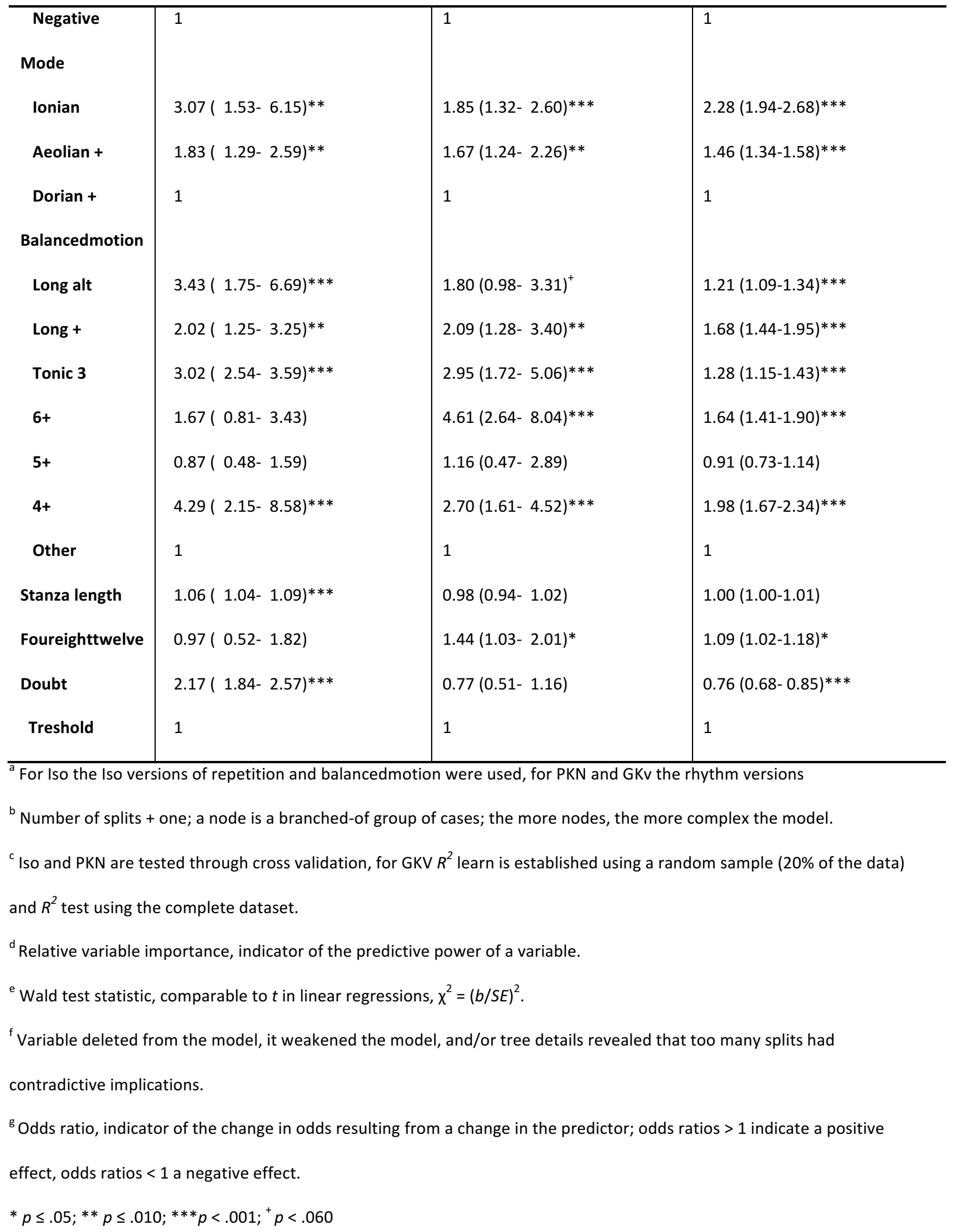


Table 8.

Regression with full models on Psalmboek

\begin{tabular}{|c|c|c|c|c|c|c|}
\hline \multicolumn{7}{|l|}{ Psalmboek } \\
\hline & Poisson SPSS & $\mathrm{CART}^{\mathrm{a}}$ & \multicolumn{4}{|c|}{ Poisson (Estimates) } \\
\hline BIC / R learn & 240500.05 & .25 & & & & \\
\hline \multirow[t]{2}{*}{$L R \chi^{2} / R^{2}$ test } & 204235.00 & .12 & & & & \\
\hline & Wald $\chi^{2 b}$ & $\mathrm{Rvi}^{\mathrm{C}}$ & Repetition & & \multicolumn{2}{|l|}{ Bal.motion rhythm $_{\text {m }}$} \\
\hline Repetition $_{\text {rhythm }}$ & $35761.14 * * *$ & 100 & $A A B$ & $1.75 * * *$ & Long alt & $1.17 * * *$ \\
\hline Bal.motion $_{\text {rhythm }}$ & $20111.40 * * *$ & 42.29 & $A A^{\prime} B$ & $1.35 * * *$ & Long + & $1.39 * * *$ \\
\hline Mode & $60993.38 * * *$ & 51.47 & $1^{\text {st }}$ line & $1.89 * * *$ & $6+$ & $1.08 * * *$ \\
\hline Contents & $21350.06 * * *$ & 0 & Late+ & $1.50 * * *$ & Tonic 3 & $1.24 * * *$ \\
\hline Foureighttwelve & $628.37 * * *^{c}$ & a & No rep. & $1.25 * * *$ & $5+$ & $1.18^{* * *}$ \\
\hline Doubt & $715.42^{* * * c}$ & a & Late- & 1 & $4+_{\text {rhythm }}$ & $1.38^{* * *}$ \\
\hline \multirow[t]{5}{*}{ Stanzalength } & $478.06 * * *^{d}$ & a & & & Other & 1 \\
\hline & & & Mode & & Contents & \\
\hline & & & Ionian & $1.59 * * *$ & Caring God & $1.37 * * *$ \\
\hline & & & Aeolian+ & $1.15 * * *$ & Praise & $1.23 * * *$ \\
\hline & & & Dorian+ & 1 & Negative & 1 \\
\hline
\end{tabular}

$\overline{{ }^{a} \text { Stanzalength, foureighttwelve and doubt are left out, they weakened the model; moreover, several splits yielded }}$ contradictive implications.

${ }^{b}$ Wald test statistic, comparable to $t$ in linear regressions, $\chi^{2}=(b / S E)^{2}$

${ }^{\mathrm{c}}$ Relative variable importance

${ }^{d}$ predicting popularity; $\operatorname{Exp}(B)$ for both doubt and foureighttwelve is $1.06 * * *$

e predicting unpopularity; $\operatorname{Exp}(\mathrm{B})$ for stanzalength is 0.99

$* * * p<.001$ 
Table 9.

Regressions with full models on contrafact scales

\begin{tabular}{|c|c|c|c|}
\hline & Cflso & America & Germany \\
\hline & EEG SPSS & Poisson SPSS & Poisson SPSS \\
\hline$B I C(d f)$ & & 2034.27 (df14) & $391.50(\mathrm{df14})^{\mathrm{a}}$ \\
\hline \multirow[t]{2}{*}{$\operatorname{LR} \chi^{2}$} & & $5429.80 * * *$ & $51.75^{* * *}$ \\
\hline & Wald $\chi^{2}$ & Wald $\chi^{2}$ & Wald $\chi^{2}$ \\
\hline Repetition $_{\text {cf }}$ & $29.92 * * *^{\mathrm{b}}$ & $375.44^{* * *}$ & $12.30^{*}$ \\
\hline Bal.motion & $36.72 * * * b$ & $642.23^{* * *}{ }^{\mathrm{c}}$ & 7.58 \\
\hline Mode & 4.06 & $1408.74 * * *$ & 3.44 \\
\hline Foureighttwelve & 0.13 & $15.49 * * *^{d}$ & 0,78 \\
\hline Stanzalength & $10.04 * *^{\mathrm{e}}$ & $316.31 * * *{ }^{\mathrm{e}}$ & $5.20 *^{\mathrm{e}}$ \\
\hline
\end{tabular}

$\overline{{ }^{a} \text { In a regression without repetition BIC is 384.36; LL39.57 (df10), balancedmotion is significant at a high level }(p<.001) \text { and }}$ stanzalength is not significant, however within balancedmotion only Long alternating is significant..

${ }^{b}$ Within repetition just $A A B$ and $1^{\text {st }}$ Line are significant predictors, within balanced motion only Long alternating and Long+ approach significance, furthermore, the categories $5+$ and $6+$ had to be combined with 'other' because of computational problems due to the absence of valid cases.

${ }^{c}$ Only $4+$ and 5+ significantly predict popularity, the other categories, except for Long+, significantly predict unpopularity,

${ }^{d}$ predicting popularity

e predicting unpopularity (i.e. shortness predicts popularity)

$* * * p<.001, * * p<.01, * p<.05$ 

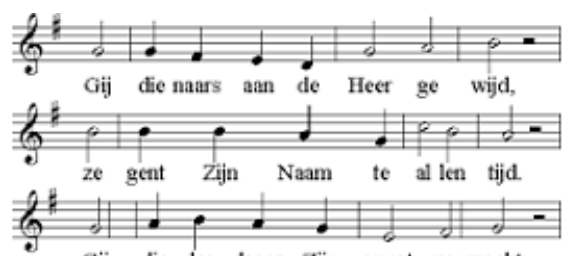

Gij die des daags Zijn gunst ver wacht,

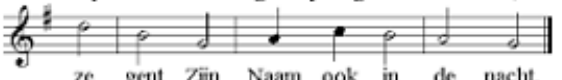

You faithful servants of the Lord,

sing out his praise with one accord,

while serving him with all your might

and keeping vigil through the night.

Figure 1. Psalm 134, melody also known as 'Old hundredth'. (Translations: Barnard (ISK, 1973, Dutch) and Koyzis (2014, English). 

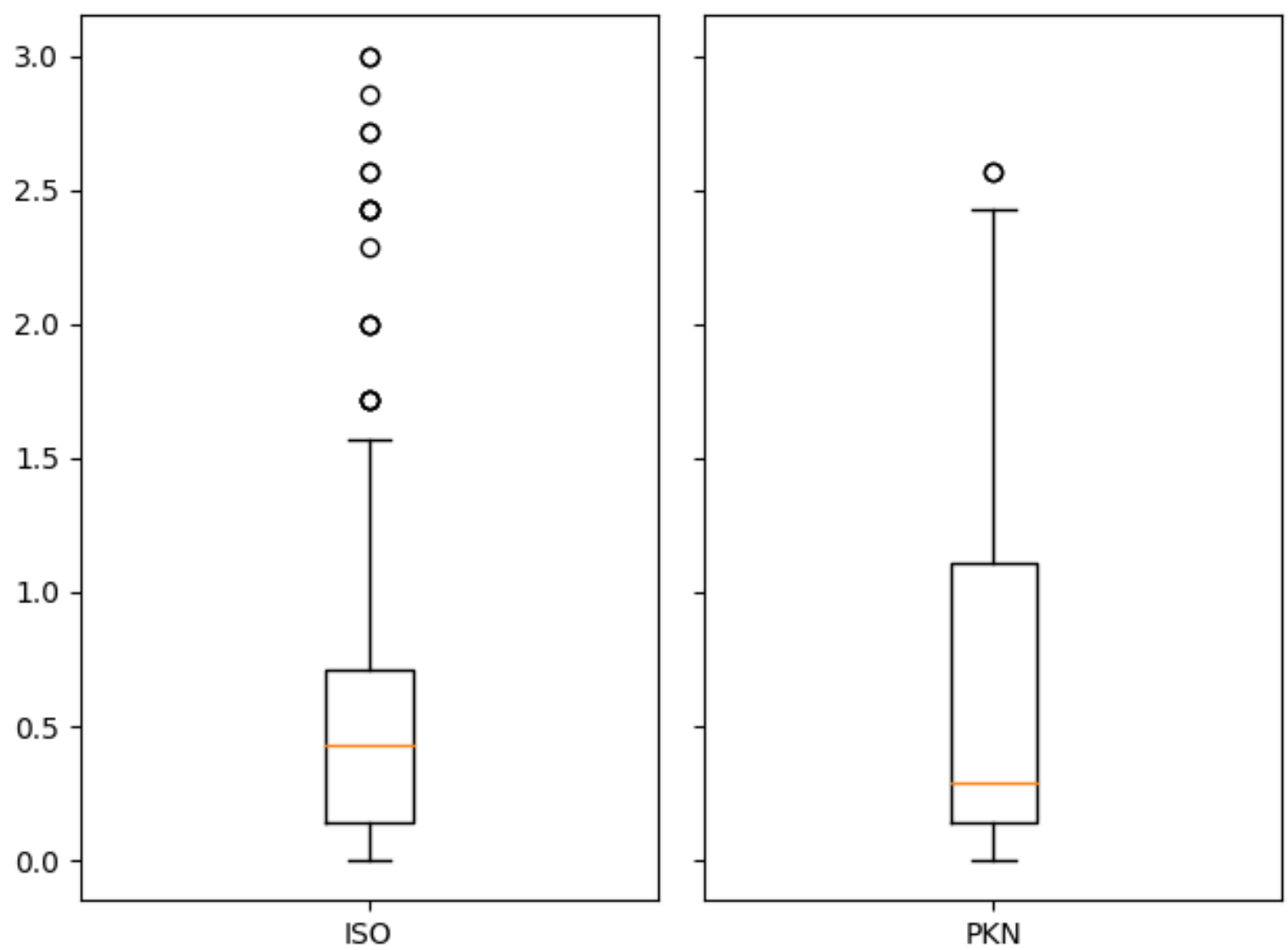

Figure 2. Boxplots of Mean Iso (left) and Mean PKN (right). In Iso fewer psalms are relatively popular than in $P K N$. 


\section{Appendix I}

Genevan melodies used twice or more in the Genevan Psalter and their use in Contrafactscales (Cf).

\begin{tabular}{|c|c|c|c|c|c|}
\hline \multicolumn{6}{|c|}{ Psalms with same melodies } \\
\hline $\ln C f$ & & Not in $C f$ & $\ln C f$ & & Not in Cf \\
\hline 5 & - & 64 & 46 & - & 82 \\
\hline 14 & - & 53 & 51 & - & 69 \\
\hline 17 & - & 63,70 & 60 & - & 108 \\
\hline 18 & - & 144 & 65 & - & 72 \\
\hline 24 & - & $62,95,111$ & 66 & - & 98,118 \\
\hline 28 & - & 109 & 74 & - & 116 \\
\hline 30 & - & 76,139 & 77 & - & 86 \\
\hline 31 & - & 71 & 78 & - & 90 \\
\hline 33 & - & 67 & 100 & - & 131,142 \\
\hline 36 & - & 68 & 177 & - & 127 \\
\hline
\end{tabular}




\section{Appendix II Pilot studies}

\section{A - Predictor variables}

Dichotomous variables:

On mode

1 Ionian, or not

2 Aeolian or Myxolidian, or not

3 Dorian or Phrygian, or not

4 Occurrence of scale-deviant notes, or not

On contents

5 Psalm about the caring God, or not

6 Psalm of praise, or not

7 Negative or outdated psalm, or not

\section{On repetitions}

$8 \mathrm{AAB}$ or $\mathrm{AA}$ 'B, or not

9 Repetition of first line (including $\mathrm{AAB}$ and $\mathrm{AA}$ 'B), or not

10 Repetition of the first line of the B-part, or not

11 Repetition elsewhere

On separation

10 (see above)

12 A tonic at the end of the first part, or not

13 Change of meter, or not

14 Change of rhyme scheme, or not

15 Change of line length, or not.

On textual aspects

16 abab-rhyme, or not

17 aabccb or baabcc rhyme, or not

18 alternating rhyme scheme $(=16+17)$, or not

19 odd numbered number of lines, or not

20 varying line lengths, or not

21 trochaic or not,

22 stanzas consist of 4,8 or 12 lines, or not

Denomination specific

23 Psalm of doubt, or not

\section{Numerical}

24 Number of lines

25 Number of lines repeated

26 Number of metrical feet per line

27 Strong separation $(=10+12+13+14+15)$

\section{B - Dependent variables}


There were regressions on six different variables:

'Totalpop' - created by simply adding up most of the scales outlined in Appendix IVa and $\mathrm{IVb}$, categorized in three categories: very popular (value 2), popular (value 1) and not popular (missing) - this scale was thought to represent the popularity of the psalms in denominations singing isometrically. However, if a melody mentioned in a scale mentioned in IVb was used also for other psalms, the value was adjusted to all the psalms associated with this melody. 'Totalpsalm' - a subset of 'totalpop' excluding the data based on Appendix IVb.

'America' - see Method section Study III.

'Germany' - see Method section Study III.

'GKv popular' - see Appendix VI.

'GKv unpopular' - see Appendix VI 


\section{Appendix III}

Repetition, segmentation, balance and motion in psalm 149 (ISK, 1973), an example.

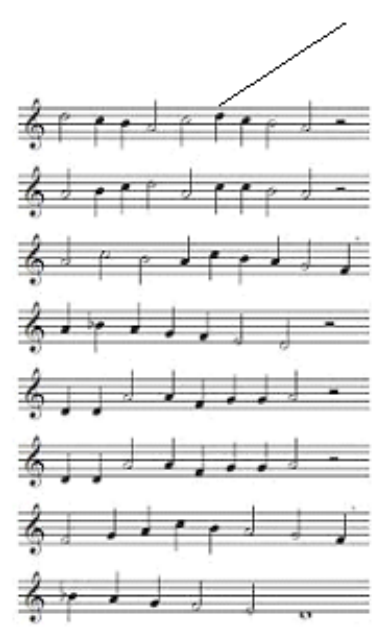

No partly repetion of 1 st line, change of musical accent

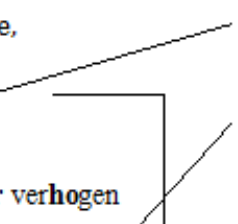

Stressed syllables bold; pattern: 44434443 .

Halleluja, laat opgetogen

Tonic stop, rhyme stop (aabb) \& grammatical stop

Een nieuw gezang de Heer verhogen

Laat allen die Gods naam belijden

Zich eensgezind verblijden.

Volk van God, loof Hem die u schiep

Istaël, dank Hem die u riep

Trek Sion in een blijde stoet

Uw Koning tegemoet. unbalanced line, shortened both by line length ( 3 instead of 4 feet) and note length (motion).

Repetition of 1st line of B-part, with caesura and clash of stresses after third note; linguistic stress well aligned; average note length smaller than first lines A-part (motion, only perceivable in rhythmic singing).

Short last line, balanced by pattern, and note length. 


\section{Appendix IV}

Psalm and melody counts derived from Smelik (1997) and other sources, worked up in Iso and Contrafacts Iso

\section{IVa. Psalm counts used for Iso}

Eight scales were created, based on five different sources: Smelik, 1997 ('Smelik'); Gunning, 1910, as cited by Smelik (1997) ('Gunning I - IV); Polder, 2001 ('Polder'), ’t Hart, 2012 ('‘t Hart') and Karels (unpublished) ('Psalmboek'). A categorized version of Karels was worked up in Iso in the pilots, in the current study we have just used the exact count separately.

Labeling and categorization of Smelik and Gunning I-IV derived from Smelik.

\begin{tabular}{|c|c|c|}
\hline Scale/Category & Count/Psalms & value \\
\hline Smelik, Hymnals & $\begin{array}{l}\text { Count of Psalms cited with or without Genevan melody in } \\
270 \text { song books and hymnals between } 1866-1938\end{array}$ & \\
\hline Psalms often cited & $\begin{array}{l}33,42,62,65,73,81,86,95,97,98,103,105,116,118,119 \\
121,130,133,134,138,139,146,150\end{array}$ & 2 \\
\hline Psalms most cited & $25,68,72,84,89,100$ & 3 \\
\hline Not reported & Rest & - \\
\hline Gunning I (Van Popta) Diaries & $\begin{array}{l}\text { Count of Psalms suggested for singing in } 9 \text { devotional diaries } \\
\text { and volumes of sermons }\end{array}$ & \\
\hline Psalms suggested $>80$ times & $25,33,68,73,84,86,89,103,118,119,146$ & 3 \\
\hline Not reported & Rest & - \\
\hline Gunning II, Rotterdam & $\begin{array}{l}\text { Count of Psalms sung in the Zuiderkerk in Rotterdam } \\
\text { between } 1864 \text { and } 1889\end{array}$ & \\
\hline Psalms sung $>150$ times & $25,42,65,72,73,84,86,89,103,116,118,134,146$ & 3 \\
\hline Psalms sung $100-150$ times & $19,33,98,105,130,133,138$ & 2 \\
\hline Not reported & Rest & - \\
\hline Gunning III (Edidi), Kampen & $\begin{array}{l}\text { Count of Psalms sung in the Gereformeerde Kerk in Kampen, } \\
\text { during } 15 \text { months ( } 48 \text { psalms never sung) }\end{array}$ & \\
\hline Psalms sung $>10$ times & $\begin{array}{l}25,27,33,65,66,68,72,73,86,89,97,98,103,116,19 \\
130,138\end{array}$ & 3 \\
\hline Not reported & Rest & - \\
\hline Gunning IV, Delfshaven & $\begin{array}{l}\text { Count of Psalms sung in the Nieuwe Kerk in Delfshaven } \\
\text { between June } 1903 \text { and October } 1909\end{array}$ & \\
\hline Psalms sung $>40$ times & $25,68,73,84,89,103,118,119,134$ & 3 \\
\hline Psalms sung 20 - 40 times & $27,32,42,65,72,86,97,105,138,146$ & 2 \\
\hline Not reported & Rest & - \\
\hline Polder (Count 2001) & $\begin{array}{l}\text { Count of psalms (including } 12 \text { Genevan hymns) sung between } \\
\text { may } 2000 \text { and may } 2001 \text { in } 13 \text { congregations singing } \\
\text { isometrically. } N=6.801 . \text { Categorization based on combining } \\
\text { authors categories. Sung once in (almost) all of the churches: } \\
\text { value 1; number of times sung is more or less on or above }\end{array}$ & \\
\hline
\end{tabular}


Psalms sung 68-352 times

Psalms sung 39-67 times

Psalms sung 12-38 times

Psalms sung $<12$ times

't Hart (Count 2012)

Psalms sung 37 - 123 times

Psalms sung 14 - 36 times

Psalms sung 7 - 22 times

Psalms sung $0-7$ times

Karels (Psalmboek) chance (chance is 42): value 2; sung about five times or more

per church: value 3.

$45,69,2,33,56,43,40,86,130,65,145,116,51,42,138$, 3

$27,32,22,73,84,72,118,105,103,68,25,89,119$

$87,21,30,63,99,74,98,34,147,16,31,62,111,133,95, \quad 2$

$143,146,77,97,134,139,79,17,81,106,66,85,36,19$,

$76,127,54,61,80,104,131,29,110,8,52,5,47,149,18, \quad 1$

$96,150,140,4,35,78,126,101,136,113,39,67,121,9,24$,

$91,92,100,115,135,141,142,107,71,6,26,123,23,37$,

$46,38,108,48,1,93,3,49,102,122,75,90,132$,

$82,129,83,88,109,114,120,10,53,58,125,137,7,13$, 0

$128,112,148,28,44,64,94,11,12,59,124,57,117,20,41$,

$55,70,14,50,144,60,15$,

Count of Psalms (including 12 Genevan hymns) prescribed in

liturgies sent to the researcher by ministers of the Hersteld

Hervormde kerk in 2012 ${ }^{1} . N=2.734$. Categorization created

by combining authors categories. Number of times sung is

more or less on or above chance (chance is 17): value 2. Half

of the categories below chance: value 1; the other half

(including the psalms sung 0 times): value 0 ; half of the

categories above chance: value 3 .

$34,80,17,9,30,95,27,33,2,65,40,84,86,72,105,21,51, \quad 3$

$89,81,32,31,69,16,116,103,118,68,25,22,119$

$3,23,36,37,110,5,6,48,74,78,136,63,88,97,77,8,62, \quad 2$

$66,79,102,107,115,143,38,99,130,133,26,134,146,42$,

$43,87,92,135,138,85,147,45,111,145,71,73,139,19$

$15,44,46,49,64,121,123,52,91,96,142,212,50,58,94,1$

$112,113,127,59,132,35,41,98,124,141,56,61,90,100$,

$108,109,122,24,106$

$7,14,20,60,76,114,125,137,148,10,11,12,28,39,54$,

0

$83,117,149,4,53,55,82,104,126,131,144,150,13,29,4$,

$53,55,82,104,126,131,144,150,13,29,18,47,57,67,70$,

$93,101,120,129,140,1,75,128$

Count of times psalms were clicked between 1-1-2013 and

31-12-2014 on the website

https://www.psalmboek.nl/zingen.php (statistics received

from M. Karels (webhost)) $)^{2}$

For this study the number of unique page visits were used,

ranging from 4750 to 40671 clicks, Mean 11540.45; SD

6628.63; Median 9392

\footnotetext{
${ }^{1}$ According to the author the number of times a psalm is sung should be divided by the number of stanzas in that psalm, because the chances that psalm 119, with its 66 stanzas, is chosen more often than a two-stanza psalm such as 150 would be bigger. To us that does not make sense. It diminishes a possible effect of melody and it does not account for the real choice of stanzas. If psalm 119:10 is chosen as often as 150:1, we think 119:10 is at least as popular as verse 150:1. Therefore we did not use his further categorization.

${ }^{2}$ According to Mr. Karels school children often use this website for rehearsing their obligatory weekly stanza to learn by heart. Probably, this might have caused a floor effect of a minimum of 5.000 clicks per psalm. Furthermore, the data concerning psalm 1 are not reliable because many people just start there, they are left missing.
}

\section{IVb: Melody counts used for Contrafacts Iso}


Four three-category scales were created, all based on information received from Smelik (1997, referring to Pollman (1965), Bakker (1994) and Bosch (1996)). For CfIso in study III all of these scales were combined in a repeated measures design.

\begin{tabular}{|c|c|c|}
\hline Scale/Category & Count/Psalms & value \\
\hline Smelik & $\begin{array}{l}\text { Count of Melodies used either for Psalms or contrafacts in } \\
270 \text { song books and hymnals between 18.. - } 1938\end{array}$ & \\
\hline Used $>\mathbf{4 5}$ times & $\begin{array}{l}24,33,65,74,81,84,89,100,138,150 \text { ( } 45-75 \text { times); } 134 \\
\text { (110 times); 36, } 42 \text { (about } 145 \text { times); } 66 \text { (190 times) }\end{array}$ & 3 \\
\hline Used $20-40$ times & $21,25,38,73,77,103,105,119,121,130,133,140$ & 2 \\
\hline Not reported & Rest & - \\
\hline Pollmann \& Luth & $\begin{array}{l}\text { Count of Melodies used for contrafacts } \pm 100 \text { song books } \\
\text { published between } 1566 \text { and } 1773\end{array}$ & \\
\hline Used $>20$ times & $6,8,9,24,36,66,74,100,130,140,23,51,79,103$ & 3 \\
\hline Not reported & Rest & - \\
\hline Bakker & $\begin{array}{l}\text { Count of Melodies used for contrafacts in song books in the } \\
\text { sixteenth, seventeenth and eighteenth century }\end{array}$ & \\
\hline Used $>60$ times & $5,6,8,9,24,36,100,140$ & 3 \\
\hline Used $30-60$ times & $23,42,66,74,79,91,103,130$ & 2 \\
\hline Not reported & Rest & - \\
\hline Bosch & $\begin{array}{l}\text { Count of Melodies used in twelve song books published } \\
\text { between } 1760 \text { an } 1810\end{array}$ & \\
\hline Melodies most used & $24,36,42,5165,66,74,84,113$ & 3 \\
\hline
\end{tabular}




\section{Appendix V}

\section{Counts and assessments of the number of times Genevan psalms are sung in PKN-}

\section{communities}

Seven four-category scales, and one exact count, were created, based on information provided by telephone or e-mail by ministers and organ players from the unorthodox part of the Protestantse Kerken in Nederland (PKN). Categorization and labeling by the informants, except for PKN Count (categorization by the first author). Values adjusted by the first author: highest category always ' 3 ', lowest ' 0 ' (never sung) or 'missing' (not reported).

\begin{tabular}{|c|c|c|}
\hline Scale/Category & Count/Psalms & value \\
\hline Organ player 1 & $\begin{array}{l}\text { Assessment of the psalms remaining popular in PKN } \\
\text { communities after the introduction of a new hymnal } \\
\text { containing much more alternative based on the experience of } \\
\text { organ player } 1 \text { and some colleagues }\end{array}$ & \\
\hline Often & $25,42,68,89,100.116,121,134,136,150$ & 3 \\
\hline Once a year per community & $43,130,149$ & 2 \\
\hline Not reported & Rest & - \\
\hline Minister 1 & $\begin{array}{l}\text { Count of Psalms suggested for singing in } 9 \text { devotional diaries } \\
\text { and volumes of sermons }\end{array}$ & \\
\hline Regularly & $\begin{array}{l}8,19,25,31,33,42,43,65,66,78,81,84,86,92,98,100 \\
103,107,111,116,118,119,121,124,136,139,146,150\end{array}$ & 3 \\
\hline Not so much & $\begin{array}{l}18,22,27,34,47,62,68,72,73,75,75,85,87,91,97,99 \\
105,122,130,133,134,138,145,147,149\end{array}$ & \\
\hline Seldom or never & Rest & - \\
\hline Minister 2 & $\begin{array}{l}\text { Assessment of Psalms sung in services led by this minister } \\
\text { during his career, according to his administration }\end{array}$ & \\
\hline Regularly & $\begin{array}{l}19,24,25,27,33,42,61,62,63,65,66,72,75,77,78,84 \\
85,87,92,97,98,99,100,105,107,116,118,121,122,136 \\
139,146\end{array}$ & 3 \\
\hline Sometimes & $\begin{array}{l}4,8,22,43,47,67,80,82,89,90,91,93,95,96,103,130 \\
149,150\end{array}$ & 2 \\
\hline Never & Rest & 0 \\
\hline Minister 3 & $\begin{array}{l}\text { Count of Genevan psalms sung in } 114 \text { services led by this } \\
\text { minister in the period 2011-2015, one psalm per service. } \\
\text { Above chance, value 2; at least once a year, value } 3 .\end{array}$ & \\
\hline Psalms sung 5-11 times & $25,68,73,84,89,103,118,119,134$ & 3 \\
\hline Psalms sung 1-4 times & $27,32,42,65,72,86,97,105,138,146$ & 2 \\
\hline Psalms sung never & Rest & 0 \\
\hline Minister 4 & $\begin{array}{l}\text { Psalms prescribed relatively often in services led by this } \\
\text { minister, after the introduction of the new hymnal }\end{array}$ & \\
\hline Psalms sung regularly & $23,84,121,139$ & 3 \\
\hline Not reported & Rest & - \\
\hline Organ player 2 & $\begin{array}{l}\text { Assessment of Genevan Psalms sung very often in PKN } \\
\text { services accompanied by this organ player between } 1960 \\
\text { and } 1990\end{array}$ & \\
\hline
\end{tabular}




\begin{tabular}{|c|c|c|}
\hline Toppers & $\begin{array}{l}25,42,43,65,66,68,72,84,87,89,90 \\
98,100,103,105,116,118,119,138,139,150\end{array}$ & 3 \\
\hline Not reported & Rest & - \\
\hline Minister 5 & $\begin{array}{l}\text { Assessment of Psalms in services led by this minister during } \\
\text { his career, according to his administration }\end{array}$ & \\
\hline Tophits & $\begin{array}{l}27,32,33,42,47,62,65,66,67,68,72,73,75,81,84,86, \\
87,89,90,95,97,98,100,103,116,118,119,121,122,138, \\
139,146,150\end{array}$ & 3 \\
\hline Psalms sung often & $\begin{array}{l}8,16,17,19,22,23,24,25,31,34,36,40,41,43,46,51,63 \\
70,71,77,78,79,85,88,91,92,93,96,97,101,102,105 \\
107,108,111,113,130,133,134,135,136,145,147,149\end{array}$ & 2 \\
\hline Psalms seldom sung & $\begin{array}{l}1,2,5,6,11,13,14,26,29,30,35,38,44,45,48,52,53,54 \\
55,56,57,61,76,80,82,104,106,109,115,117,120,123 \\
124,126,131,132,137,143,148\end{array}$ & 1 \\
\hline Psalms never sung & $\begin{array}{l}3,4,7,9,10,12,15,18,20,21,28,37,39,44,50,58,59,60, \\
64,69,74,83,94,110,112,114,127,128,129,140,141 \\
142,144\end{array}$ & 0 \\
\hline
\end{tabular}




\section{Appendix VI}

'Psalms of doubt' and Psalmcount GKv by H.N. Werkman (1991; 1992)

\begin{tabular}{ll}
\hline Category & Psalms \\
\hline Psalms asking 'Why' (Psalms of Doubt) $^{1}$ & $6,10,13,22,30,35,38$ 39, 42, 43, 44, 56, 63, 64, 69, \\
& $73,74,77,80,88,89,102,130,142,143$ \\
\hline
\end{tabular}

Results of a Psalm count during five years in four churches of the Gereformeerde Kerken vrijgemaakt ${ }^{2}$ Psalms sung very often

$16,19,90,103$,

Psalms sung relatively often

$23,25,32,36,56,84,94,100,105,111,116,118$,

$122,130,145$

Psalms hardly ever sung

$10,17,20,38,39,41,44,54,58,59,60,64,69,70$,

$74,77,82,83,88,94,107,109,129,137,140,142$

\footnotetext{
${ }^{1}$ Used as a predictor variable in the regressions in both Study II and Study III

2 During the pilots the first two groups were used together in a dependent variable 'GKv popular', and the last category in a dependent variable 'GKv unpopular'.
} 